$\begin{gathered}\text { Ana Dili Eğitimi Dergisi } \\ \text { Journal of Mother Tongue Education } \\ \text { www.anadiliegitimi.com }\end{gathered}$
Gelis/Received: 10.08 .2018 Kabul/Accepted:18.09.2018

\title{
Türkçenin Yabancı Dil Olarak Öğretiminde Edmodo'nun Kullanımı: Bir Durum Çalışması
}

\author{
Halit KARATAY* \\ Hüseyin KARABUĞA** \\ Ozan IPEK ${ }^{* * *}$
}

\begin{abstract}
Öz
Bu çalışmada, WEB 2.0 araçlarından Edmodo'nun Türkçenin yabancı dil olarak öğretiminde kullanımı incelenmiştir. Araştırma, durum çalışması şeklinde tasarlanmıştır. Çalışma, BAiBÜ TÖMER'de öğrenim gören B2 düzeyindeki 20 öğrenci ve bu öğrencilerin derslerine giren 2 öğretim elemanı ile yürütülmüştür. Edmodo, Türkçe öğretimini destekleyici araç olarak B2 kurundan itibaren 8 hafta boyunca kullanılmıştır. Sekiz hafta sonunda öğrencilerle yarı yapılandırılmış EUGF kullanılarak uygulama hakkında öğrenci görüşleri alınmıştır. Ayrıca uygulama sürecinde öğretim elemanlarının uygulama hakkındaki gözlemleri de dikkate alınarak incelenmiştir. Öğrencilere göre Türkçe öğreniminde Edmodo kullanımı; dil becerilerinin geliştirilmesine, yeni sözcük ve söz öbeklerinin, dil bilgisi kurallarının, hedef kültürün ve farklı kültürlerin öğrenilmesine, Türkçe öğrenme ilgisine ve isteğine katkılar sağlamıştır. Öğretim elemanlarına göre Türkçe öğretiminde Edmodo kullanımının, öğrencilere dönüt verme, onlarla etkileşim kurma, ölçme ve değerlendirme, işbirlikli öğrenme, öğrenme sorumluluğu kazandırma ve teknoloji okuryazarlığı gibi alanlarda yararları vardır. Ayrıca öğrenci görüşlerine ve öğretim elemanları gözlemlerine göre Edmodo'nun, erişilebilirlik, kullanım kolaylığı, ücretsiz olma, Türkçe dil desteği, farklı uygulamalarla uyum ve araç zenginliği gibi “kullanışlılık özellikleri”ne sahip olduğu belirlenmiştir. Buna rağmen, Edmodo'nun internet bağlantısı olmadan çalışmaması, anlık sohbet özelliğine sahip olmaması, tasarım özellikleri bakımından beklentilere cevap verememesi gibi bazı tasarım sorunlarına ve teknik sorunlara sahip olduğu belirlenmiştir. Genel olarak elde edilen veriler, Edmodo'nun Türkçenin yabancı dil olarak öğretiminde destekleyici ve yararlı bir öğrenme aracı olduğunu göstermiştir.
\end{abstract}

Anahtar Kelimeler: Türkçenin yabancı dil olarak öğretimi (TYDÖ), Edmodo, WEB 2.0, durum çalışması.

\section{The Use of Edmodo in Teaching Turkish as a Foreign Language: A Case Study}

\begin{abstract}
In this study, the use of Edmodo, which is a WEB 2.0 tool, in teaching Turkish as a foreign language was examined. The research was designed as a case study. The study was conducted with 20 students at the B2 level in BAIBÜ TÖMER and 2 instructors who taught Turkish as a foreign language courses to those students. Edmodo was used as a supporting tool for teaching Turkish for 8 weeks from the beginning of the B2 level. At the end of 8 weeks, student opinions were sought regarding the use of the application, by using a semi-structured EUGF. In addition, observations about the application of the instructors in the implementation process were examined. According to the students, the use of Edmodo in learning Turkish contributed to improving their language skills, learning new words and phrases, learning the rules of language knowledge, learning the target
\end{abstract}

\footnotetext{
* Prof. Dr., Bolu Abant İzzet Baysal Üniversitesi Eğitim Fakültesi, Bolu, halitkaratay@gmail.com

** Öğr. Gör., Bolu Abant İzzet Baysal Üniversitesi TÖMER, Bolu, hsynkarabuga@gmail.com

${ }^{* * *}$ Arş. Gör., Bolu Abant İzzet Baysal Üniversitesi Eğitim Bilimleri Enstitüsü, Bolu, ozan-ipek@hotmail.com
} 
culture and different cultures, and increasing interest and desire of learning Turkish. According to the teaching staff, the use of Edmodo in teaching Turkish had benefits in areas such as giving feedback to students, interacting with them, measuring and evaluating, cooperative learning, learning responsibility and technological literacy. In addition, based on the students' opinions and observations of the instructors, it was determined that Edmodo has "utility features" such as accessibility, ease of use, being free of charge, providing language support in Turkish, being adaptable to different applications and providing a wealth of features. Nevertheless, it was determined that Edmodo does not work without an internet connection, that it does not have an instant chat feature, and that it causes technical problems such as its failing to satisfy expectations because of design faults. The data obtained in general show that Edmodo is a supportive and useful learning tool for teaching Turkish as a foreign language.

Keywords: Teaching Turkish as a foreign language (TTFL), Edmodo, WEB 2.0, case study.

\section{Giriş}

Bilgiye erişimin kolaylaştığı ve iş birliğinin egemen olduğu çağımızda, teknoloji insan yaşamının her alanını giderek çevrelemektedir. Teknoloji alanında yaşanan hızı gelişmeler, bireylerin ve toplumların yaşam tarzlarını, öğrenme anlayışlarını da etkilemekte ve değiştirmektedir. İnsan hayatında yaşanan bu değişimler ise bireylerin edinmesi ve geliştirmesi gereken becerileri etkilemekte (Solomon ve Schrum, 2007) ve eğitim ile teknoloji arasındaki iş birliğini gözler önüne sermektedir. Eğitimde yaşanan gelişmeler teknolojiyi, teknolojide yaşanan gelişmeler ise birçok alanın yanı sıra, eğitimi de etkilemektedir.

Bu yüzyılda, bireylerin yaşadıkları zamana ve koşullara ayak uydurmaları ve başarılı olmaları için gereken bilgi ve beceriler vardır. Bunlar 21. yüzyıl becerileri olarak adlandırılmaktadır. Bu beceriler üç temel alana ayrılır:

1. Yaşam ve kariyer becerileri,

2. Öğrenme ve yenilik becerileri (eleştirel düşünme, iletişim, işbirlikli öğrenme, yaratıcılık),

3. Bilgi, medya ve teknoloji becerileri (Partnership for 21st Century Skills, 2018).

Bireylerin gelişen ve değişen yaşam koşullarına uyum sağlaması için bu temel becerilere sahip olması gerekir. Eğitim alanında çalışanlar da bu becerileri edinmeli ve eğitim ortamlarında bunları etkili şekilde kullanabilmelidir. Özellikle eğiticiler için bilgiyi esnek kullanma, medya ve teknoloji okuryazarlı̆̆ı becerileri önemlidir.

Alanyazında 21. yüzyıl becerilerine ilişkin ortaya konan bakış açısına göre bu becerilerden özellikle dijital okuryazarlık önemli bir beceriyi temsil etmektedir (Kurt ve Orhan, 2015, s.68). Teknoloji ve eğitim, 21. yüzyılda birbirinden ayrılamaz iki kavram olmuştur. Bu bakımdan teknoloji ve eğitiminin tarihte hiç olmadığı kadar birbirini desteklediğini söylemek yanlış olmaz. Günümüzde teknolojinin hem öğrencilere hem de eğiticilere sunduğu olanaklar, öğretim ile teknolojiyi bütünleştirmeyi kaçınılmaz kılmaktadır. Diğer yandan, teknolojinin sunduğu olanaklardan yararlanmayan eğitim, çağın bireysel ve toplumsal beklentilerine yanıt veremeyebilir. 
Eğitimle ilgili birçok alanda olduğu gibi dil öğretiminde de teknoloji kullanımı oldukça önemlidir. Teknolojinin vazgeçilmez bir araç olduğu günümüzde, dil öğrenenlerin hem bilişsel hem de duyuşsal özelliklerine hitap eden ve erek dilin öğrenilmesinde onlara katkı sağlayan eğitsel ağlar ve uygulamalar gibi dijital öğrenme ortam ve araçlarının kullanımı yaygınlaşmaktadır. Bugün birçok öğrenci dil öğrenirken cep telefonundan etkin bir şekilde yararlanmakta, bilgisayar üzerinden öğrenme ortamlarına katılmakta, çeşitli bilgi ve iletişim yazılımlarıyla erek dille daha kolay iletişime geçebilmektedir. Bunun için öğretmenler, dil öğretirken çeşitli öğretim teknolojilerinden yararlanmaktadır.

Son yıllarda eğiticiler, Türkçenin yabancı dil olarak öğretimi alanında da teknolojiden yararlanmaya başlamıştır. Bunlar arasında en yaygın olanları, uzaktan öğretimi destekleyen mobil eğitim ortamları, bilgisayar destekli eğitim ve z-kitap kullanımıdır. Türkçeyi yabancı dil olarak öğreten kursların teknolojiyi öğretim süreçlerinde etkin şekilde kullanabilmeleri, çağın gereklerinden birisi hâline gelmiştir. Diğer yandan teknoloji geniş bir yelpazeyi içine alan çatı bir kavramdır. Teknolojinin pek çok yüzü ve aracı bulunmaktadır. Bu bakımdan dil öğretiminde en iyi sonuçlara ulaşmak için öğretilecek konuya, bununla edindirilecek becerinin özelliğine ve eğitimdeki maliyetine göre çeşitli teknolojik araçlar ve uygulamalar tercih edilebilir.

Dil öğretim ortamlarında sıklıkla kullanılan teknolojilerden biri de internet tabanlı WEB 2.0 araçlarıdır. WEB 2.0 kavramı, "World Wide Web"in ikinci kuşağını tanımlamak için kullanılmaktadır (Ajjan ve Hartshorne, 2008; Horzum, 2010). WEB 2.0, ağ kullanıcılarının daha fazla etkileşim ve iş birliği sağlamaları (Durmuş, 2015), daha yaygın bağlantıları kullanmaları ve iletişim ağları kurmaları amacıyla geliştirilmiş güncel, çevrimiçi bir teknolojidir. Bu bakımdan WEB 2.0 çerçevesinde geliştirilen araçlar, ilk kuşak WEB araçlarına göre çeşitli farklılıklar göstermektedir. WEB 2.0 ile birlikte basit içerik dağıtımı yerine, etkileşimci paylaşım ve katılımcı iş birliği öne çıkmıştır.

Türkçe öğretiminde WEB 2.0 araçlarının etkin olarak kullanımı, bireylerin yaratıcılığını, işbirlikli çalışma ve iletişim kurma becerilerini geliştirir. Zira bu araçlar, 21. yüzyıl öğrencilerinin ihtiyaç duyduğu becerilerin geliştirilmesi için olanak yaratır (Solomon ve Schrum, 2007). Türkçenin yabancı dil olarak öğretiminde kullanılabilecek WEB 2.0 araçları; sosyal ağlar (Facebook, Twitter, Edmodo vb.), wikiler, bloglar, podcastler, İnstagram, Pinterest, video paylaşım siteleri ve anlık mesajlaşma programları vb. olarak sıralanabilir. Bunların içerisinde dil öğretiminde en yaygın şekilde kullanılanı Edmodo'dur. Bunun için bu çalışmada, Edmodo'nun tanıtılması ve Edmodo'nun Türkçe öğretimine etkilerinin gözler önüne serilmesi amaçlanmıştır. Çalışmadan elde edilen verilerin, konunun ilgililerine benzer uygulamaları kullanmak veya aynı uygulama üzerinden farklı etkinlikler tasarlamak için yol gösterici olacağı düşünülmüştür. 


\section{Edmodo Uygulaması}

Edmodo, öğrencilerin intiyaç duydukları insanlarla bağlantı kurmasına ve kaynaklara ulaşmasına yardımcı olan küresel bir eğitim ağıdır (Edmodo, 2018). Yazılımı mobil araçlarca desteklenmekte ve birçok farklı uygulamayla bütünleşik çalışabilmektedir. Edmodo uygulaması, her düzeydeki (K-12) öğrenciler, öğretmenler, yöneticiler ve ebeveynler için tasarlanmıştır (Durmuş, 2015; Edmodo, 2018). Edmodo uygulaması 90 farklı ülkeden 400 bin kayıtlı okula ve toplamda 85 milyon kullanıcıya sahiptir (Edmodo, 2018). Edmodo, Facebook gibi basit bir ara yüze sahip olması (Durak, Çankaya ve Yünkül, 2014), içerisinde farkı ölçme-değerlendirme araçlarını barındırması (Ekmekçi, 2016), öğretmenlerin ve öğrencilerin internet bağlantısına sahip herhangi bir yerden çok farklı türdeki dokümanlara ulaşım sağlaması (Dere, Yücel ve Yalçınalp, 2016; Torun ve Dargut, 2015), öğrencilere kontrol edilebilir ve güvenilir bir ortam sağlaması (Türkmen, 2012), ailelerin çocuklarının gelişimini kolayca takip edebilmesi (Edmodo, 2018), öğretmenlerin farklı ülkelerdeki meslektaşlarıyla bilgi alışverişinde bulunması gibi farklı olanaklara sahiptir. (Alemdağ, 2013). Edmodo, bu özelliklerinden dolayı milyonlarca insan tarafından kullanılan ücretsiz bir eğitsel araçtır.

Edmodo uygulaması, öğretmenlerin kendi özel sınıflarını oluşturarak bu sınıflarda çok farklı Edmodo araçlarını ve diğer WEB 2.0 araçlarını kullanıp öğrenme ve öğretme süreçlerini zenginleştirmelerine; öğretmenlerin, öğrencilerine ve velilerine kolaylıkla ulaşmalarına; öğrencilerin istedikleri yerlerden ders süreçlerine katılmalarına ve ilgili dokümanları takip edebilmelerine; velilerin de çocuklarının gelişimlerinden haberdar olmalarına imkân veren zengin bir içerik sistemine sahiptir. Bu zengin içerik sisteminde öğretmenlerin ve öğrencilerin kullanımına sunulan not, ödev, sınav (quiz), anket, rozetler, uyarı, kütüphane, sırt çantası, Edmodo planlayıcısı, ilerleme vb. bölümler mevcuttur. Edmodo sahip olduğu bu farklı araçlarla eğitimcilerin ve araştırmacıların da dikkatini çekmiştir.

Edmodo uygulamasının eğitsel amaçlarla kullanımına yönelik olarak alanyazında birçok araştırma bulunmaktadır. Bu araştırmalardan bazıları, Edmodo'yu tanıtan ve nasıl kullanılabileceğini açıklayan derleme tarzı çalışmalardır (Alemdağ, 2013; Durak, Çankaya ve Yünkül, 2014; Holzweiss, 2013; Sırakaya, 2015). Bunların devamında, çeşitli bilim dallarından üniversitedeki öğretim elemanlarının, okullardaki öğretmenlerin (Kongchan, 2008; Özkan, 2017) ya da öğretmen adaylarının (Kazez ve Bahçeci, 2016; Polat, 2016; Sırakaya, 2015) Edmodo hakkındaki görüşlerini inceleyen çalışmalar; Edmodo kullanımını öğrenci görüşleri çerçevesinde ele alan çalışmalar da (Aydın ve Demirer, 2016; Baştuğ, Solmaz, Kaledibi ve İşbulan, 2016; Dere, Yücel ve Yalçınalp, 2016; Ekmekçi, 2016; Enriquiz, 2014; Hamutoğlu ve Kıyıcı, 2017; Kazez ve Bahçeci, 2016; Polat, 2016) vardır. Edmodo'nun öğretim aracı olarak kullanılabilirliğini ve kullanım kolaylığını (Alemdağ, 2013; Balasubramanian, Jaykumar ve Fukeyb, 2014; Durak, Çankaya ve Yünkül, 2014; Holland ve Muilenburg, 2011; Holzweiss, 2013; Kuzgun ve Özdin, 2017; Sırakaya, 2015; Türkmen, 2012); farklı beceri 
alanlarında öğrenci başarısına etkisini (Nee, 2014; Özkan, 2017; Sanders, 2012); öğrenme ilgisine ve isteğine etkisini (Al-Kathiri, 2015; Aytan ve Başal, 2015; Özkan, 2017; Türkmen, 2012; Yaman, 2014); öğrenci-öğrenci, öğretmen-öğrenci etkileşimine etkilerini (Alemdağ, 2013; Aytan ve Başal, 2015; Dewi, 2014; McClain, Brown ve Price, 2015; Polat, 2016; Torun ve Dargut, 2015) inceleyen çalışmalar da vardır. Ayrıca Edmodo'nun diğer sosyal ağ siteleriyle karşılaştırılması üzerine çalışmalar da (Dogoriti, 2015; Durak, Çankaya ve Yünkül, 2014) yapılmıştır. Ancak bu araştırmalarda Edmodo'nun Türkçe öğretiminde kullanımı üzerine bir çalışmanın yapılmadığı belirlenmiştir. Öte yandan, Türkçenin yabancı dil olarak öğretiminde Edmodo kullanımına yönelik öğrenci görüşlerini ve öğretim elemanlarının gözlemlerini içeren bir araştırma da yoktur. Araştırmanın Türkçeyi yabancı dil olarak öğrenenlerin farklı beceri alanlarının geliştirilmesinde kullanılabilecek yeni bir aracı tanıtması ve bu aracın yararlarını ortaya koyması bakımından alana katkı sağlayacağı düşünülmüştür. Buradan hareketle araştırmada, Türkçenin yabancı dil olarak öğretiminde Edmodo kullanımının derinlemesine incelenmesi amaçlanmıştır. Bu amaç çerçevesinde aşağıdaki sorulara yanıtlar aranmıştır:

1. BAіBÜ TÖMER'de okuyan öğrencilerin Türkçe derslerinde Edmodo kullanımına ilişkin görüşleri nelerdir?

2. BAіBÜ TÖMER'de görev yapan öğretim elemanlarının Türkçe derslerinde Edmodo kullanımına ilişkin gözlemleri nelerdir?

\section{Yöntem}

\section{Araştırmanın Yöntemi ve Modeli}

$\mathrm{Bu}$ araştırma, nitel araştırma yöntemlerinden durum çalışması şeklinde desenlenmiştir. Durum çalışması, gerçek yaşamın, güncel bağlam ya da ortam içerisindeki bir durumun araştırılmasıdır (Creswell, 2016). Olgu ve olayların derinlemesine incelenmesi, durum çalışmalarının en temel niteliklerinden biridir. Bu çalışmaların amacı, bir ya da birkaç durum hakkında derinlemesine bilgi sağlamak ve anlayış geliştirmektir (Gliner, Morgan ve Leech, 2015). Araştırmada Türkçeyi yabancı dil olarak öğrenen B2 düzeyindeki öğrencilerin Edmodo'nun Türkçe derslerinde kullanımına ilişkin görüşleri incelenmiştir. Ayrıca, öğretim elemanlarının bu uygulamayla ilgili gözlemleri de analiz edilerek Edmodo'nun Türkçe öğretimine sağladığı katkılara ilişkin veriler sunulmuştur. Bunun için öğretim elemanları 8 haftalık B2 kuru boyunca derslerinde Edmodo uygulamasını kullanmışlardır. Öğretim sürecinde Edmodo uygulamasından iki şekilde yararlanılmıştır:

1. Ders içi uygulamalar: Ders içinde yaratıcı yazmaya dönük grup çalışmalarında; yazım, noktalama ve dil bilgisi konuları ile ilgili bazen dönüt-düzeltme, bazen ölçme ve değerlendirme çalışmalarında; söz varlığının inşa edilmesi için bağlama uygun sözcük ve söz öbekleri kullanma etkinliklerinde Edmodo'dan yararlanılmıştır. 
2. Ders dışı uygulamalar: Ders dışında telaffuzun iyileştirilmesi; okuma, okuduğunu anlama ve değerlendirme; dinleme, dinlediğini anlama ve değerlendirme; yaratıcı yazma; yazım, noktalama ve dil bilgisi kurallarının öğretimi ve pekiştirilmesi ile söz varlığının inşa edilmesi için bağlama uygun sözcük ve söz öbeklerini kullanma çalışmalarında; Türk kültürüne ait milli ve dini bayramların, giyim-kuşam, yeme-içme özelliklerinin, mitlerin ve âdetlerin öğretiminde Edmodo'dan yararlanılmıştır.

\section{Çalışma grubu}

Bu araştırmada çalışma grubu, nitel durum çalışmasının temel yapısına uygun olarak amaçlı örnekleme yoluyla belirlenmiştir. Amaçlı örnekleme, "belli ölçütleri karşılayan ve belli özelliklere sahip olan bir veya daha fazla özel durumlarda çalışılmak istenildiğinde tercih edilir" (Büyüköztürk, Çakmak, Akgün, Karadeniz, Demirel, 2014, s.90). Akademik dil becerilerinin önem kazandığı Türkçe öğrenme basamağı B2 kurudur. Bu düzey, öğrencilerin tutarlı metin oluşturma, bağlama uygun söz ve söz öbeklerini kullanma, yazım ve noktalama kurallarını doğru uygulama, sözcükleri doğru sesletme, etkili dinleme stratejileri geliştirme gibi becerilerin kazandırıldığı, hatalı olanların iyileştirilmesi için yoğun çalışmaların yapıldığı bir dil öğrenme sürecidir. Bu süreç öğrenciyi akademik Türkçeye hazırlar. Bu hazırlığın hem sınıf içinde hem sınıf dışında zenginleştirilmiş öğretim etkinlikleriyle donatılması gerekmektedir. Türkçeyi yükseköğretime devam edecek kadar öğrenme ihtiyacı duyan öğrencilerin dil öğrenme zamanlarını genişletme, etkili ve verimli kullanmalarını sağlama amacıyla onların ilgilerini çekebilecek, ihtiyaçlarına cevap verebilecek, kolay ulaşılabilir, WEB 2.0 gibi destekleyici öğretim araçlarına ihtiyaç vardır. Bu doğrultuda WEB 2.0 araçlarından da farklı dil becerilerine aynı anda hitap eden Edmodo uygulamasının kullanımına, bu uygulamanın öğrencilere ve öğretim sürecine katkılarıın incelenmesine karar verilmiştir. Araştırmanın çalışma grubunu, Bolu Abant İzzet Baysal Üniversitesi Türkçe Öğretimi Uygulama ve Araştırma Merkezinde öğrenim gören ve yükseköğretime devam etmek isteyen B2 düzeyindeki 20 öğrenci oluşturmuştur. Aynı kurumda öğrencilerin derslerine giren ve dil öğretim sürecinde Edmodo'yu etkin şekilde kullanabilen iki öğretim elemanı da araştırmanın çalışma grubunda öğretim sürecini yapılandırma ve süreci gözlemleme görevleri ile yer almıştır. Çalışma grubunun demografik özellikleri Tablo 1'de verilmiştir.

Tablo 1. Çalışma Grubunun Demografik Özellikleri

\begin{tabular}{|c|c|c|c|c|c|c|c|}
\hline $\begin{array}{c}\text { Çalışma } \\
\text { Grubu }\end{array}$ & Ülke & Yaş & Cinsiyet & Çalışma Grubu & Ülke & Yaş & Cinsiyet \\
\hline 1. Katılımcı & Irak & 21 & Erkek & 12. Katılımcı & Türkmenistan & 21 & Kadın \\
\hline 2. Katılımcı & Irak & 40 & Erkek & 13. Katılımcı & Kırgızistan & 19 & Kadın \\
\hline 3. Katılımcı & Irak & 38 & Kadın & 14. Katılımcı & Afganistan & 45 & Erkek \\
\hline 4. Katılımcı & Irak & 35 & Erkek & 15. Katılımcı & Sudan & 20 & Erkek \\
\hline 5. Katılımcı & Irak & 26 & Erkek & 16. Katılımcı & Irak & 21 & Kadın \\
\hline 6. Katılımcı & Irak & 18 & Kadın & 17. Katılımcı & Irak & 21 & Kadın \\
\hline 7. Katılımcı & Irak & 23 & Kadın & 18. Katılımcı & Irak & 20 & Kadın \\
\hline 8. Katılımcı & Suriye & 25 & Erkek & 19. Katılımcı & Irak & 19 & Erkek \\
\hline 9. Katılımcı & Irak & 24 & Erkek & 20. Katılımcı & Irak & 22 & Kadın \\
\hline
\end{tabular}




$\begin{array}{llllllll}\text { 10. Katılımcı } & \text { Irak } & 22 & \text { Erkek } & \text { 21. Öğr. Elemanı } & \text { Türkiye } & 32 & \text { Erkek } \\ \text { 11. Katılımcı } & \text { Bangladeş } & 24 & \text { Erkek } & \text { 22. Öğr. Elemanı } & \text { Türkiye } & 29 & \text { Erkek }\end{array}$

\section{Veri Toplama Araçları ve Süreci}

Durum çalışmasının en temel özelliklerinden biri, veri toplama konusunda çeşitlilik gerektirmesidir (Creswell, 2016; Çepni, 2014; Merriam, 2015; Paker, 2015). Bu çeşitliliği sağlamak amacıyla Edmodo uygulamasıyla ilgili hem öğrenci görüşlerinden hem de öğretim elemanları gözlemlerinden yararlanılmıştır. Edmodo uygulaması ile ilgili ayrıntılı ve derinlemesine veri çeşitliliğini sağlamak için yarı yapılandırılmış, açık uçlu sorulardan oluşan ve öğrencilerin yazılı olarak doldurabileceği "Edmodo Uygulamasıyla İlgili Görüşme Formu" B2 kurunun sonunda öğrencilere verilmiştir. Ayrıca veri toplama sürecinde yüz yüze görüşme ve gözlem tekniklerinden de yararlanılmıştır. Öğrencilerle uygulama hakkında yapılan yüz yüze görüşmeler, EUGF'de anlaşılmayan veya yeteri kadar yanıtlanmayan sorularla ilgili durumların öğrencilere açıklanması ve bu yolla ayrıntılı ve derinlemesine veri elde edilmesini sağlamak amacıyla kullanılmıştır. Veri toplama süreciyle ilgili araştırma deseni Tablo 2'de verilmiştir.

Tablo 2. Araştırmada Kullanılacak Veri Toplama Araçları

\begin{tabular}{lccc}
\hline Ölçme Aracı & $\begin{array}{c}\text { Ölçme } \\
\text { Aracının Kullanım Amacı } \\
\text { Edmodo'yo ilişkin sınıf } \\
\text { 1. Gözlem }\end{array}$ & $\begin{array}{c}\text { Ölçme Aracının } \\
\text { Kime Uygulanacağı }\end{array}$ & $\begin{array}{c}\text { Ölçme Aracının } \\
\text { Yaklaşımı }\end{array}$ \\
$\begin{array}{l}\text { 2. Yarı } \\
\text { yapılandırı̈ımış } \\
\text { görüşme }\end{array}$ & $\begin{array}{c}\text { Edmodo'ya ilişkin öğrenci } \\
\text { görüşlerinin saptanması }\end{array}$ & Öğretici \\
3. Yüz yüze görüşme & $\begin{array}{c}\text { Edmodo'ya ilişkin öğrenci } \\
\text { görüşlerinin saptanması }\end{array}$ & Örenci & Nitel \\
\hline
\end{tabular}

Edmodo uygulamasının Türkçe öğrenmeye sağladığı katkılara ilişkin öğrenci görüşlerini belirlemek amacıyla araştırma kapsamında 13 soruluk yarı yapılandırılmış "Edmodo Uygulamasıyla İlgili Görüşme Formu" hazırlanmıştır. Yarı yapılandırılmış görüşmelerde, sorular görüşme öncesinde hazırlanır ve görüşme anında esnek davranılabilir. Bu tür görüşmelerde soruların sırası değiştirilebilir ve ihtiyaç halinde sorular daha ayrıntılı olarak açıklanabilir (Çepni, 2014, 172-173, Şimşek ve Yıldırım, 2013). Görüşme formu hazırlanırken öncelikle konuyla ilgili alanyazın taranmış ve benzer araştırmalardan yararlanılmıştır. Görüşme sorularının açık ve anlaşılır olmasına dikkat edilmiştir. Soruların, öğrencilerin görüşlerini gerçekçi şekilde yansıtabilmesi adına yönlendirici nitelikte olmamasına dikkat edilmiştir. Öncelikle 20 soruluk bir görüşme formu hazırlanmıştır. Hazırlanan sorular kolaydan zora ve genelden özele doğru bir aşamalııı ile sıralanmıştır. Öğrencilerin konuyla ilgili görüşlerinin derinlemesine tespiti amacıyla görüşme formunda açık uçlu sorulara yer verilmiştir. Tasarlanan görüşme formundaki soruların geçerliğine yönelik olarak üç alan uzmanının görüşüne başvurulmuştur. Uzmanlar, Türkçenin yabancı dil olarak öğretimi alanında araştırma yapan 
Türkçenin Yabancı Dil Olarak Öğretiminde Edmodo'nun Kullanımı: Bir Durum Çalışması

akademisyenlerden seçilmiştir. Uzmanlardan gelen dönütlere göre görüşme formu yeniden düzenlenmiş ve formun 13 soruluk son şekline karar verilmiştir. Bu form üzerinden bir öğrenci ile ön uygulama yapılarak soruların veri toplamaya uygun olduğu tespit edilmiştir. EUGF çalışma grubundaki bütün öğrencilere cevaplamaları için verilmiştir. EUGF'de anlaşılmayan veya yeteri kadar yanıtlanmayan sorularla ilgili durumların öğrencilere açıklanması ve bu yolla ayrıntılı ve derinlemesine veri elde edilmesini sağlamak amacıyla çalışma grubundaki öğrencilerle yüz yüze görüşmeler de yapılmış ve verilen yanıtlar ses kaydına alınmıştır. Bunun için veri toplama sürecinde iki araştırmacı görev almıştır. Bu araştırmacılardan ilki görüşme formundaki soruları yöneltip ses kaydı almış, ikincisi ise görüşme sürecini gözlemleyerek gerektiğinde sorularla ilgili açıklama ve genişletme yapmıştır. Bu doğrultuda, görüşme formu üzerinden konu daha derinlemesine ve ayrıntılı ele alınmıştır.

Öğretim elemanları 8 haftalık B2 kuru boyunca derslerinde Edmodo uygulamasını kullanarak öğrencilerin dil becerilerini geliştirecek öğretim etkinlikleri paylaşmış ve bu etkinlikleri öğrencilere yaptırmıştır. Bu öğretim etkinlikleri şunlardır: Ders içinde yaratıcı yazma, yazım ve noktalama (5 etkinlik), dil bilgisi (5 etkinlik), söz varlığını zenginleştirme (10 etkinlik) etkinlikleri yapılmıştır. Ders dışında ise telaffuz (10 etkinlik), okuma ve okuduğunu anlama (10 etkinlik), dinleme ve dinlediğini anlama (20 etkinlik), yazma, yazım ve noktalama ( 5 etkinlik), dil bilgisi ( 5 etkinlik), söz varlığını zenginleştirme (15 etkinlik), kültür aktarımı (15 etkinlik) etkinlikleri yapılmışır. Öğretim elemanları Edmodo üzerinden yapılan her etkinlikle ilgili gözlemler yapmıştır. Bu gözlemler Edmodo'nun Türkçe öğretimine, eğitsel süreçlere katkısına ve kullanışlılığına yönelik olup her hafta raporlaştırılmıştır.

\section{Verilerin Analizi}

Araştırmada, EUGF ile elde edilen nitel verilerin çözümlenmesinde içerik analizi tekniği kullanılmıştır. İçerik analizi, "metin veya metinlerden oluşan bir kümenin içindeki belli kelimelerin veya kavramların varlığını belirlemeye yönelik yapılır. Araştırmacılar bu kelime ve kavramların varlığını, anlamlarını ve ilişkilerini belirleyip analiz ederek metinlerdeki mesaja ilişkin çıkarımlarda bulunurlar" (Büyüköztürk, vd., 2014, s.246). Katılımcılardan elde edilen veriler birkaç kez okunmuş ve verilere derinlemesine bakılmıştır. Edmodo kullanımına dair öğrenci görüşleri ve öğretici gözlemleri, araştırmanın analiz birimleri olarak belirlenmiştir. Ardından belirlenen bu analiz birimleri arasında kavramsal bağlantılar kurulmuş, kendi içerisinde bağlantılı olan kavramlardan ana ve alt temalardan oluşan kodlama kategorileri belirlenmiştir. Bunlar üzerinden Edmodo kullanımının Türkçe öğrenmeye katkısına, eğitsel yararlarına ve kullanışlılığına yönelik temalar belirlenmiştir. Bu temalara yönelik katıımcı görüşleri “... (K1), ... (K2), ...”; öğretim elemanlarının uygulama sürecindeki gözlemleri de “... (ÖG1), ... (ÖG2)” şeklinde kodlanmıştır. Uygulamayla ilgili her tema altındaki öğrenci görüşleri birleştirilmiş, bunlarla ilgili yorumlarda ve değerlendirmelerde bulunulmuştur. Son olarak öğretim elemanlarının EUGF'ye kaynak olan uygulama süreciyle ilgili gözlemleri aynı temalar altında tablolar 
halinde sunulmuştur. Buna göre Türkçenin yabancı dil olarak öğretiminde Edmodo uygulaması ile ilgili öğrenci görüşleri ve öğretim elemanları gözlemlerinin içerik analizi sonucunda şu ana ve alt temalara ulaşılmıştır:

1. Edmodo'nun Türkçe öğrenmeye ve öğretmeye katkısı: temel dil becerileri, yeni sözcük ve söz öbeklerinin öğrenimi-öğretimi, dil bilgisi kurallarının öğrenimi-öğretimi, hedef kültürün ve farklı kültürlerin öğrenimi-öğretimi, Türkçe öğrenme ilgisine ve isteğine katkısı.

2. Edmodo'nun eğitsel süreçlere katkısı: geri bildirim verme, etkileşim kurma, ölçme ve değerlendirme, işbirlikli öğrenme, öğrenme sorumluluğu kazandırma ve teknoloji okuryazarlığı.

3. Edmodo'nun kullanışlılığ: erişilebilirlik, kullanım kolaylığı, ücretsiz olma, Türkçe dil desteği, farklı uygulamalarla uyum, araç zenginliği; teknik sorunlar, sürekli internet bağlantısı gerektirme, anlık sohbet içermeme ve programın sayfa tasarımının ilgi çekici olmaması.

Böylelikle Edmodo uygulamasının Türkçe öğretimine katkıları hakkında konunun ilgililerine hem öğrencilerin hem de öğretim elemanlarının gözünden derinlemesine ve ayrıntılı veriler sunulmuştur.

\section{Bulgular}

\section{Edmodo Ile Illgili Öğrenci Görüşleri}

Bu bölümde Edmodo uygulamasının "Türkçe öğrenmeye katkısına, eğitsel yararlarına ve kullanışlılığına" dair öğrenci görüşlerine yer verilmiştir.

\subsection{Türkçe Öğrenmeye Katkısı Ile ilgili Görüşler}

Tablo 3. Edmodo'nun Türkçe öğrenmeye katkısı

\begin{tabular}{lcc}
\hline Türkçe öğrenmeye katkısı & $\mathbf{f}$ & $\%$ \\
\hline 1) Temel dil becerilerinin gelişimine katkısı & 19 & 25,4 \\
2) Sözcük ve deyimlerin öğrenimine katkısı & 18 & 24,0 \\
3) Kültürlerarası etkileşime katkısı & 16 & 21,3 \\
4) Türkçe öğrenme ilgisine ve isteğine katkısı & 12 & 16,0 \\
5) Türkçe dil bilgisi kurallarını öğrenmeye katkısı & 10 & 13,3 \\
\hline Toplam & 75 & 100 \\
\hline
\end{tabular}

Tablo 3'te, uluslararası öğrencilerin Edmodo'nun Türkçe öğrenimine katkıları hakkındaki görüşlerine yer verilmiştir. Buna göre öğrenciler, en çok "temel dil becerilerinin gelişmesi", "yeni sözcük ve söz öbekleri öğrenilmesi" ve "hedef kültürün ve farklı kültürlerin öğrenilmesi" gibi konularda Edmodo uygulamasının kullanışlı ve yararlı olduğunu belirtmişlerdir. Öğrencilerin Edmodo'nun Türkçe öğrenimine katkıları hakkındaki görüşleri şunlardır: 
1) Temel Dil Becerilerine Katkıları

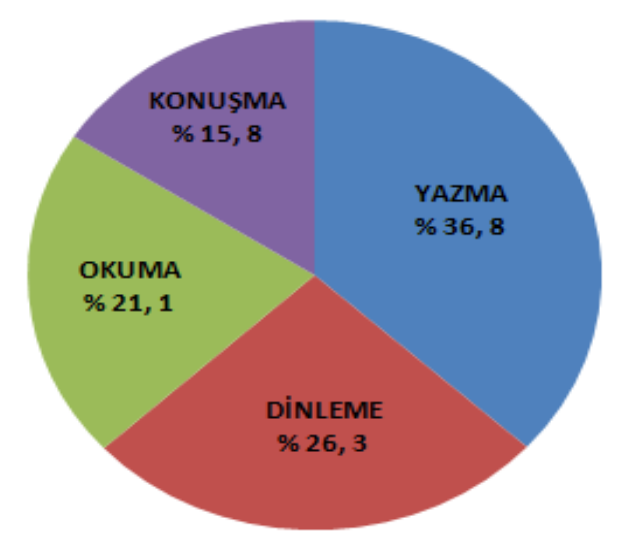

Grafik 1. Temel Dil Becerilerini Geliştirmeye ilişskin Öğrenci Görüşleri

Grafik 1'de, öğrencilerin Edmodo'nun temel dil becerilerinin geliştirilmesine katkıları hakkındaki görüşlerinde en çok "yazma", "dinleme" ve "okuma" temalarına değindikleri belirlenmiştir. Bu konudaki öğrenci görüşleri aşağıda verilmiştir:

\section{Yazma Dil Becerisiyle Ilgili Öğrenci Görüşleri}

Edmodo kullanımı sayesinde öğrenciler; yazılı anlatım becerilerinin geliştiğini, bunun yanında yazım ve noktalama kurallarını öğrendiklerini belirtmişlerdir. "Edmodo yazmamı geliştirdi. Şimdi benim yazmam daha iyi. Yazım ve noktalama kurallarını öğrendim. Edmodo hatalarımın azalmasına yardım etti." (K6). "Yazma becerisi için Edmodo kullanmak çok iyi oldu. Ve noktalama, yazım kurallarını öğrenmek için de çok faydalı oldu. Şimdi ben bu konuları çok iyi yapıyorum. Yazma kurallarını çok iyi ögrrendim çünkü Edmodo'da herkes bir şey yazıyor. Hocam, bizim yazdıklarımızı okuyor ve düzeltiyor. Böylece ne hatalar yaptığımı, yapıldığını biliyorum." (K8). "Edmodo çok faydalı ve iyi. Edmodo ile yazmak daha kolay. Edmodo ile daha kolay yazı yazmaya başladım. Yazmam gelişti." (K20).

Edmodo kullanımıyla öğrenciler; yazııı anlatımlarıyla ilgili hatalarını kolayca fark edebildiklerini ve öğretmenlerinden aldıkları dönütlerle konuları daha iyi öğrenebildiklerini belirtmişlerdir. Bu uygulamada öğretmenin öğrenci çalışmalarıyla ilgili dönütleri kalıcı öğrenmeyi kolaylaştırmıştır. "Edmodo'da arkadaşlarımla bir şeyler paylaşıyoruz. Bu paylaşımların altına yorumlar yazarken hatalarımı fark ediyorum ve düzeltiyorum." (K2). "Edmodo yazmamı çok geliştirdi. Bir şey yazınca ögrretmen yazımı kontrol ediyor. Böylece hatalarımı anladım." (K18).

\section{Dinleme Dil Becerisiyle Ilgili Öğrenci Görüşleri}

Edmodo kullanımı sayesinde öğrenciler; yapılan dinleme çalışmalarıyla telaffuz hatalarını fark ettiklerini, özellikle erek dili konuşan birinin sesinden bir dinleme metnini dinleyerek Türkçe seslerin 
farkına vardıklarını belirtmişlerdir. "Türkçeyi iyi konuşmak için iyi dinlemek gerekiyor. Biz Türkleri pek dinlemediğimiz için Türkçeyi iyi konuşamıyorduk. Çünkü ben hatalarımı görmüyordum. Mesela ben bir kelimeyi on defa okuyordum ama her defasında başka okuyordum. Ama ben o kelimeyi bir defa bir Türk'ten duyunca bir Türk gibi o kelimeyi söyleyebilirim. Edmodo paylaşımları telaffuzumu geliştirdi." (K12). "Edmodo ile dinlemem gelişti. Bu program bana yardım etti. Bazı kelimelerin doğru telaffuzunu öğrendim. Ben bazen çok hızı okuyorum ama Edmodo'da çok dinleme yapınca nasıl okumam gerektiğini öğrendim." (K19). Bu durum, onların konuşurken telaffuzlarının gelişmesine, Türkçeyi daha iyi konuşmalarına; okurken de metinleri daha anlaşılır bir ses tonuyla ve hızıyla okumalarına katkı sağlamıştır. "Dinlemem Edmodo sayesinde daha iyi oluyor çünkü Edmodo'da ses kayıtları paylaşıyoruz. Onları çok dinliyorum."(K5). "Hoca her gün bizimle bir şey paylaşıyor. Mesela her gün metinleri önce kendisi okuyup ses kaydı yapıyor ve bunu bizimle paylaşıyor. Bu bizim için çok yararlı. Yani okumamızı ve dinlememizi geliştiriyor ve okumayı, dinlemeyi öğretiyor." (K10). Edmodo uygulaması öğrencilerin Türkçe seslerin farkına varma ve kullanma becerilerini geliştirmeye yardımcı olmuştur.

\section{Okuma Dil Becerisiyle Illgili Öğrenci Görüşleri}

Edmodo kullanımı sayesinde öğrenciler; yapılan çalışmalarla okuma hatalarını fark ettiklerini, bu sayede akıcı okuma becerilerini geliştirdiklerini ve okuma alışkanlığı edindiklerini belirtmişlerdir. "Edmodo'yu sürekli kullanınca telaffuzumuz, akıcı okumamız gelişti. Edmodo okuma becerisi için çok faydalı çünkü hocamız metinleri okuyup ses kaydı yaptı. Biz evde bunları dinleyip nasıl okumamız gerektiğini öğrendik. Bu şekilde telaffuzumuz düzeldi. Türkçe okuma alışkanlığı kazanmak için de Edmodo çok faydalı. Edmodo sayesinde kitap taşımadan her yerde okumak mümkün oldu. Mesela her yere kitap götürmek mümkün olmuyor ama Edmodo'yu her yere götürebilirsiniz." (K3). "Edmodo'daki paylaşımlar daha hızlı okumamı sağladı çünkü Edmodo'da çok okuma yapıyorum." (K6). Ayrıca uygulamanın taşıma maliyetinin düşük olması öğrenciye kullanım ve erişim kolaylığı sağlamıştır.

“...Edmodo sayesinde kitap taşımadan her yerde okumak mümkün oldu. Mesela her yere kitap götürmek mümkün olmuyor ama Edmodo'yu her yere götürebilirsiniz." (K3). Bunun yanında, hazırlanan dinleme metinleri, öğrencilerin Türkçenin sesletim özelliklerinin farkına varmalarına yardımcı olmuş, kendi kendilerine bir metni sesli okurken de bunları uygulama için bir öğrenme modeli sunmuştur. "Edmodo programı çok iyi bir program. Çünkü ben çok yeni kelime öğrendim. Benim okumam çok zayıftı. Edmodo'da metinleri dinledikçe okuma hatalarımı fark ettim. Şimdi okumam daha iyi." (K7). "Hocamı metinleri okuyup ses kaydı yapıyor. Bunları dinleyince telaffuzu, vurguyu ve tonlamayı öğrenmemize yardımcı oluyor. Ben hızlı konuşuyorum ve okuyorum. Ben bunları dinleyince nasıl okumam gerektiğini, nerede durmam gerektiğini öğrendim. Bana bu konularda çok yardım etti.” (K11). 
Türkçenin Yabancı Dil Olarak Öğretiminde Edmodo'nun Kullanımı: Bir Durum Çalışması

Konuşma Dil Becerisiyle Illgili Öğrenci Görüşleri

Edmodo kullanımı sayesinde öğrenciler; yapılan çalışmalarla konuşmanın sesletimden sonra tamamlayıcısı olan beden dilini kavradıklarını, ayrıca konuşma ve dinleme becerilerini geliştirdiklerini belirtmişlerdir. "Edmodo'da paylaşılan videolar insanların beden dilini anlamayı etkiledi ve bana yardımcı oldu." (K4). "Özellikle telaffuzu öğrenmek için bu uygulama çok önemli. Çünkü biz önceden, ders dışında bir Türk'ü dinlemiyorduk. Türkçeyi iyi konuşmak için iyi dinlemek gerekiyor." (K12). "Edmodo'daki paylaşımlar rahat konuşmama yardımcı oldu." (K15).

\section{2) Sözcük ve Deyimlerin Öğrenilmesine Katkıları}

Edmodo kullanımı sayesinde öğrenciler, sözcük ve deyimleri kolayca öğrendiklerini belirtmişlerdir. "Edmodo yeni kelimeler öğrenmeme katkı sağladı. Bazı kelimeleri görünce merak edip sözlüğe bakıyorum." (K9). "Bence Edmodo yeni sözcük kazanmak için faydalı. Özellikle deyimlerde çok faydalı." (K12). "Edmodo sayesinde yeni kelimeler ve deyimler öğrendim." (K16).

\section{3) Kültürlerarası Etkileşim}

Türk Kültürüyle Etkileşim

Edmodo kullanımı sayesinde öğrenciler; Türk kültürünün birçok özelliğini öğrendiklerini belirtmişlerdir. "Edmodo'daki bazı videolar Türk kültürünü anlatıyordu. Mesela Türk danslarını öğrendim. Türk kültürünü daha iyi öğrendim." (K5). "Edmodo üzerinden Türk kültürü hakkında birçok şeyler öğrendim." (K9)."Edmodo'da paylaşılan videolarla Türk kültürünü iyice öğrendim. Mesela Türk kahvesini ve düğün zamanı erkeklere neden tuzlu kahve verildiğini öğrendim." (K20).

Farklı Kültürlerle Etkileşim

Edmodo'da yapılan video paylaşımları sayesinde öğrenciler, farklı kültürlerin birçok özelliğini öğrendiklerini belirtmişlerdir. "Edmodo üzerinden yapılan paylaşımlar, farklı kültürleri tanımamı sağladı." (K4). "Edmodo uygulamasında çok farklı kültürleri öğreniyorum. Arkadaşlar kendi kültürlerinden yemekler, giysiler ve başka şeyler paylaşıyor." (K14).

4) Türkçe Öğrenme Ilgisini ve Isteğini Arttırması

Edmodo uygulaması ile öğrenciler, Türkçeyi eğlenerek öğrendiklerini ve bu durumun onların Türkçe öğrenme ilgisini ve isteğini arttırdığını belirtmişlerdir. "Edmodo'da arkadaşlarla ve öğretmenle birlikte dil öğrenmek eğlenceli hâle geliyor." (K8). "Edmodo programı bize çok motivasyon verdi. Çünkü hep beraber Edmodo'da okuyoruz ve düşüncelerimizi paylaşıyoruz." (K10). "Edmodo öğrenmeyi eğlenceli yapıyor. Yani öğrenmek eğlenceli geliyor. Gerçekten yani Edmodo hoşuma gitti. Ben memnunum ve kullanıyorum." (K14). 


\section{5) Türkçe Dil Bilgisi Kurallarını Öğrenmeye Katkısı}

Edmodo kullanımı sayesinde öğrenciler; yapılan çalışmalarla dil bilgisi kurallarını daha iyi kavradıklarını, derslere gelmedikleri dönemlerde de dil bilgisi konularını öğrenebildiklerini ve uygulamadaki görseller ve sunumlar sayesinde dil bilgisi kurallarını kolayca kavrayabildiklerini belirtmişlerdir. "Edmodo gramere çok yardımcı oldu. Çünkü o, ek ders verir gibi oluyor." (K13). "Edmodo paylaşımları derste öğrendiğimiz kuralları tekrar etmemize yardım ediyor. Okula gelmesen de dersteki kurallara tekrar bakabilirsin." (K17). Uygulama, dil bilgisi ile ilgili öğrenme konularını videolar ve resimler aracılığıyla somutlaştırmış, ayrıca öğrencilerin yere ve zamana bağımlı olmadan kendi kendilerine konuları öğrenmelerine ve tekrar etmelerine olanak sağlamıştır. "Dil bilgisi kurallarını anlatan videolar ve resimler çok yararlı oldu. Çünkü bazı kuralları bunlarla daha iyi öğrendim." (K1).

\subsection{Eğitsel Yararları ile ilgili Görüşler}

Tablo 4. Edmodo'nun eğitsel yararları

\begin{tabular}{lcc}
\hline Öğretim sürecine katkıları & $\mathbf{f}$ & $\mathbf{\%}$ \\
\hline 1) Geri bildirim & 17 & 23,0 \\
2) Etkileşim & 15 & 20,3 \\
3) Ölçme ve değerlendirme & 13 & 17,5 \\
4) İşbirlikli öğrenme & 12 & 16,2 \\
5) Öğrenme sorumluluğu & 10 & 13,5 \\
6) Teknoloji okuryazarlığı & 7 & 9,5 \\
\hline Toplam & 74 & 100 \\
\hline
\end{tabular}

Tablo 4’te öğrencilerin Edmodo uygulamasının öğretim sürecinde kendilerine sağladığı eğitsel yararlar hakkındaki görüşlerine yer verilmiştir. Öğrencilere göre, Edmodo uygulaması "geri bildirim", "etkileşim", "ölçme ve değerlendirme" gibi öğretim sürecinin etkin katılım, dönüt ve düzeltme ilkelerine daha fazla katkı sağlamıştır. Bu uygulama sayesinde öğrenciler, öğrenme sürecine etkin bir şekilde katılmış, öğretim etkinlikleri hakkında kendilerine dönüt ve düzeltme yapılmasını yararlı bulmuşlardır. Ayrıca öğrenciler, Edmodo’nun, onların “işbirlikli öğrenme”, öğrenme sorumluluğu üstlenme" ve "teknoloji okuryazarlığı" becerilerinin gelişimine katkı sağladığını belirtmişlerdir.

\section{1) Geri Bildirim}

Edmodo uygulaması ile öğrenciler, yazılı anlatımlarındaki hataları fark ettiklerini ve öğretmenin hatalarla ilgili dönüt vermesi sayesinde bu hataları tekrar etmediklerini belirtmişlerdir. "Edmodo'da hocamın yorumlarımı okuması ve hatalarımı düzeltmesi güzel oldu. Bu, yanlışlarımı düzeltmeye yardımcı oldu. Böylece yanlışlarımı tekrarlamadım." (K3). "Edmodo yazma becerimi geliştirdi çünkü Edmodo'da yapılan hataları hoca hemen düzeltti. Edmodo hatalarımın azalmasına yardımcı oldu ve bana katkı sağladı." (K16). Ayrıca öğrenciler; uygulamadaki etkinliklerin doğru yapılması halinde verilen ödüllerin onların Türkçe öğrenme ilgisini ve isteğini arttırdığını, onlara verilen ödevleri yapmaya ve küçük sınavlara katılmaya daha istekli olduklarını belirtmişlerdir. "Edmodo'da ödevler, sınavlar ve bazı 
Türkçenin Yabancı Dil Olarak Öğretiminde Edmodo'nun Kullanımı: Bir Durum Çalışması

ödüller (rozet) var. Edmodo'daki sistemi çok beğendim. Ayrıca çok modern bir yöntem." (K1). "Edmodo çok iyi bir öğretmen gibi. Hatalarımızı görmek ve soru sormak çok kolay. Onu daha fazla kullanmalıyı." (K19).

2) Etkileşim

Edmodo uygulaması sayesinde öğrenci-öğrenci, öğrenci-öğretmen etkileşiminin arttığı, fikir paylaşmanın ve bunlarla ilgili dönüt almanın kolaylaştığı belirlenmiştir. "Edmodo, öğretmenimizle iletişim kurmamızı kolaylaştırdı." (K7). "Edmodo'da arkadaşlarımla hızlıca iletişim kurabilirim. Ve yardıma gerek olursa öğretmene hemen soru sorabilirim." (K11). "Edmodo diğer öğrencilerle iletişim kurmayı kolaylaştırdı. Diğer öğrencilerle fikirler paylaşmayı kolaylaştırdı. Edmodo, soru sormayı daha kolaylaştırdı ve her zaman sorulara cevap almayı sağladı." (K13). Yani uygulama onlara, etkileşimli bir öğrenme ortamı sunmuştur.

3) Ölçme ve Değerlendirme

Edmodo uygulamasındaki küçük sınavlar, öğrencilerin dil becerilerindeki hatalarını fark etmelerini, gerektiğinde hatalarına dönüp bakarak bunları bir daha tekrar etmemelerini sağlamıştır. “Edmodo'da ödevler ve sınavlar yaptık. Bunlar bence faydalı oldu. Gerçek sınava hazırlanırken her şeyi hatırlamamıza yardımcı oldu. Gerçek sınava hazırlandım." (K15). "Edmodo'daki anlık sınavlar ve ödevler benim için çok faydalı oldu çünkü hocam hep hatalarımı düzeltti, bana anlattı. Bir de not olmaması çok güzel çünkü böyle rahat hissettim." (K18). Ayrıca, bu ölçme-değerlendirme çalışmaları onların kur sonu sınavlarındaki kaygılarını da azaltmıştır. "... Bir de not olmaması çok güzel çünkü böyle rahat hissettim." (K18). "Edmodo sınava çok yardım etti. Her zaman kullanmak için bir kaynağımız olduğunu bilmek bizi biraz daha rahatlattı." (K17).

\section{4) Işsirlikli Öğrenme}

Sınıftaki işbirlikli öğrenme etkinliklerini Edmodo sayesinde sınıf dışında da yapmak mümkündür. "Edmodo ile sınıfta grup çalışması yaptık ve bunları Edmodo üzerinde paylaştık. Ve diğer grupların paylaşımlarını tahlil ettik. Böylece birlikte çok şey öğrendik." (K9). "Edmodo üzerinden sınıf dışında grup çalışmaları çok yaptık. Birlikte ders çalıştık. Birlikte bir şeyler hazırladık. Edmodo'da birlikte hızlıca öğrendik." (K15). Bu uygulama öğrenciler için hem sınıf içindeki hem de sınıf dışındaki öğretim etkinliklerinin paylaşılması, birlikte düzeltilmesi için yararlı bir öğretim ortamı sağlamıştır. "Edmodo'da birlikte hepimiz çalışıyoruz. Bir konu ya da sorun olunca onun üstünde çalışırken birbirimizden yeni bir şeyler öğreniyoruz." (K2). 


\section{5) Öğrenme Sorumluluğu}

Edmodo uygulaması, öğrencilerin kendilerini izleme, hatalarını kendi kendilerine düzeltme olanağı sunmuştur. "Edmodo kendi kendime öğrenmemi arttırdı. Mesela, yorumları yazarken doğru mu, yanlış mı yazdığıma dikkat ediyorum." (K4). "Edmodo dil öğrenmeme çok yardımcı oldu. En çok da yazmama yardımcı oldu. Geçmişten bugüne kadar yapılan tüm paylaşımlarla Türkçeyi ne kadar iyi öğrendiğimi gördüm." (K6). "Edmodo programı kendi hatalarımı görmeme ve hatalarımı telafi etmeme yardımcı oldu. Edmodo ile ilerlediğimi hissettim. Edmodo beni ve Türkçemi çok geliştirdi." (K11). "Edmodo'da çok iyi Türkçe öğrendim ve ne kadar çok kullanırsam Türkçeyi o kadar iyi öğrenirim." (K18). Uygulama sayesinde öğrenciler, dil öğrenme sürecinde öz denetim becerisi kazanmışlardır.

6) Teknoloji Okuryazarlığı

Edmodo uygulaması, öğrencilerin teknoloji okuryazarlığı becerilerini geliştirmiştir. "Edmodo kullanmak interneti öğrenmemize yardım etti." (K1). "Edmodo'da farklı yerlerden bir şeyler paylaşıyoruz ve onlara kolay ulaşabiliyoruz. Bunlar interneti rahat kullanmama yardımcı oldu." (K3). Öğrenciler dinleme ve telaffuz çalışmalarında Edmodo'dan sıkça yararlanmış ve bu durum, öğrencilerin birtakım becerilerini geliştirmelerine de yardımcı olmuştur. Ayrıca Edmodo kullanımı, öğrencilerin Türkçe öğreniminde farklı dijital ortamlardan ve araçlardan yararlanmalarına önayak olmuştur. "Edmodo, teknolojiyi rahat kullanmama yardımcı oldu. Mesela, ses kaydı yapmayı bilmiyordum. Edmodo üzerinden ses kaydı yapmayı öğrendim." (K10). "Edmodo interneti kullanarak Türkçe öğrenmemizi sağladı. Daha önce internetten Türkçe öğrenebileceğim aklıma gelmemişti. Ama şimdi Youtube'de, Instagram'da pek çok hesabı ve kanalı takip ediyorum." (K19).

\subsection{Kullanışlı Bir Öğretim Aracı Olması Ile Illgili Görüşler}

Tablo 5. Edmodo'nun öğretim aracı olarak kullanışııı̆̆ı

\begin{tabular}{lcc}
\hline Edmodo'nun kullanışlılığı & $\mathbf{f}$ & $\%$ \\
\hline 1) Erişilebilirlik & 17 & 28,3 \\
2) Kullanım kolaylığı & 15 & 25,0 \\
3) Ücretsiz olma & 12 & 20,0 \\
4) Türkçe dil desteği & 7 & 11,7 \\
5) Farklı uygulamalarla uyum & 5 & 8,3 \\
6) Araç zenginliği & 4 & 6,7 \\
\hline Toplam & 60 & 100 \\
\hline
\end{tabular}

Tablo 5’te, öğrencilerin Edmodo'nun kullanışlılığına ilişkin olumlu görüşlerine yer verilmiştir. Buna göre öğrenciler Edmodo'nun en çok "erişilebilirlik", "kullanım kolaylığı" ve "ücretsiz olma" gibi özelliklerini beğenmişlerdir. Bunların dışında Edmodo'nun "Türkçe dil desteği"ne sahip olması, "farklı uygulamalarla uyum" içerisinde çalışması ve sahip olduğu "araç zenginliği" öğrencilerce beğenilmiştir. Tüm bunlarla ilgili öğrenci görüşlerine aşağıda yer verilmiştir: 


\section{1) Erişilebilirlik}

Öğrenciler, öğretim sürecinin açmazlarından olan belli bir zamana ve mekâna bağıı olma zorunluluğundan kurtulduklarını, Edmodo sayesinde ders içeriklerine ve öğretmene istedikleri yerden istedikleri zaman ulaşabildiklerini belirtmişlerdir. "Edmodo'yu her yerde kullanabiliriz. Bu program sınıf gibi ama onu her yerde ve her zaman kullanabiliriz." (K8). "Edmodo dil öğrenmeyi çok kolaylaştırır. Edmodo özel bir öğretmen gibi ama o, her zaman yanımızda olur." (K11). Öğrenciler, okula gelmedikleri günlerde dersleri Edmodo üzerinden takip edebildiklerini ve bu durumun Türkçe öğrenmeyi kolaylaştırdığını vurgulamışlardır. "Okula gelmediğim günlerde Edmodo üzerinden yapılan paylaşımlarla derslerden geri kalmıyorum." (K14).

2) Kullanım Kolaylığı

Öğrenciler Edmodo'yu kullanışı ve kolay bir uygulama olarak değerlendirmiştir. "Edmodo çok kolay bir uygulamadır. Edmodo kullanışIı." (K8). "Edmodo, Facebook gibi bir şey. Kullanması kolay." (K17). Kullanım kolaylığı sağlayan bu uygulama öğrencilerin kendilerini rahat hissetmelerini de sağlamıştır. "Edmodo kullanmak çok kolay ve ben kullanırken rahat hissediyorum." (K7).

\section{3) Ücretsiz Olma}

Öğrencilere göre Edmodo, hem ücretsiz bir uygulama hem de dil öğrenmek için farklı bir öğretim aracıdır. "Bu programı her yerde kullanabiliriz ve bu program ücretsiz." (K5). "Edmodo kolay bir uygulama ve ücretsiz." (K13). "Edmodo bir dili farklı şekilde öğrenmeyi sağlıyor ve ücretsiz." (K19).

\section{4) Türkçe Dil Desteği}

Edmodo'nun kullanım dilinin Türkçe olması, öğrencilerin uygulamanın sunduğu Türkçe terimleri öğrenmelerine katkı sağlamıştır. "Edmodo Türkçe bir uygulama ve birçok şey öğrenmemizi sağladı." (K2). "Edmodo Türkçe bir program. Edmodo ile Türkçem ilerledi." (K20). Başlangıçta zorlansalar da daha sonra uygulamayı kullanmaya alışınca bu uygulama öğrencilerin hoşuna gitmiş ve onların Türkçelerini geliştirmeye yardımcı olmuştur. "Türkçe bir programı ilk defa kullandım. Başlarda zorlandım ama biraz sonra öğrendim. Türkçe program kullanmak güzel oldu." (K16).

\section{5) Farklı Uygulamalarla Uyum}

Edmodo'nun farklı uygulamalarla ve internet sayfalarıyla uyumlu olması, kolayca kullanılması öğrencilerce beğenilmiştir. "Edmodo'yla farklı internet sayfalarına ve uygulamalara ulaşıyoruz. Edmodo'yu rahat kullanıyorum." (K6). Öğrenciler bu durumun onların teknolojik okuryazarlıklarını geliştirdiğini belirtmişlerdir. "Edmodo farklı programları kullanmama yardımcı oldu. Teknolojiyi daha rahat kullanabilirim." (K9). " Edmodo ile farklı uygulamaları da kullandık. Teknolojiyi daha rahat kullanmama yardımcı oldu." (K10). 


\section{6) Araç Zenginliği}

Edmodo'nun sahip olduğu not, ödev, sınav (quiz), anket, rozetler, uyarı, kütüphane, sırt çantası, Edmodo planlayıcısı gibi özellikleri öğrencilerce beğenilmiştir. "Edmodo öğretmen ile kolay iletişim kurmamızı sağlıyor. İstediğimiz videoyu, ses kayıtlarını, metinleri ya da sunumları paylaşıyoruz." (K2). “Edmodo'da ödev ve sınav yapıyoruz. İstediğimiz zaman Edmodo'daki kaynaklara ulaşabiliyoruz. Edmodo'da hocamız sınavları ya da ödevleri hatırlatıyor. Bizlere bir şeyler hatırlatmak için Edmodo'yu kullanıyor. İstediğimiz zaman birbirimize ya da hocamıza mesaj atabiliyoruz. Edmodo faydalı bir program." (K12). Öğrenciler bu araçların sunduğu öğretim etkinliklerini beğenerek kullandıklarını belirtmişlerdir.

Tablo 6. Edmodo kullanımındaki sorunlar

\begin{tabular}{lcc}
\hline Edmodo'daki sorunlar & $\mathbf{f}$ & \% \\
\hline 1) Teknik sorunlar & 7 & 53,8 \\
2) Sürekli internet bağlantısı & 3 & 23,1 \\
3) Anlık sohbet içermeme & 2 & 15,4 \\
4) Programın sayfa tasarımı & 1 & 7,7 \\
\hline Toplam & 13 & 100 \\
\hline
\end{tabular}

Tablo 6'da, öğrenciler, telefonlardaki farklı yazılımlardan doğan "teknik sorunlar", "sürekli internet bağlantısı" gerektirme, "anlık sohbet içermeme" ve "programın sayfa tasarımı"nın ilgi çekici olmaması nedenleriyle Edmodo'yu yetersiz bulmuşlardır. Bunlarla ilgili öğrenci görüşleri sırasıyla aşağıda verilmiştir:

Uygulama hakkında öğrencilerin öğretim aracı olarak belirttiği yararlara rağmen uygulamanın bazı teknik ve tasarım sorunları olduğu da belirtilmiştir: "Edmodo'daki bazı videolar açılmıyor." (K7). "Bu program bazı telefonlarda çalışmıyor." (K14). "Edmodo'yu iyi kullanmak için pahalı telefon lazım. Sistemde bazen sıkıntı oluyor." (K18). "Edmodo'nun olumsuz bir yanı var. Kullanmak için sürekli internet Iazım." (K15). "Edmodo'nun sevmediğim bir yanı var. İçinde chat yapmak için bir yer yok. Mesaj yazılıyor ama ben bazen herkese bir şey sormak istiyorum. Keşke Edmodo'da chat olsa." (K19). “Edmodo'yu kullanmak kolay ama biraz şekli iyi değil. Mesela, Facebook gibi ama onun gibi renkli değil. Bence Edmodo daha güzel olabilir." (K4). Öğrenciler tarafından belirtilen bu sorunların iyileştirilmesi halinde Edmodo uygulaması daha ilgi çekici ve kullanışlı olabilir.

\section{2. Öğretim Elemanlarının Edmodo Uygulaması Etkinliklerine Yönelik Gözlemlerine Illişkin Bulgular}

Bu bölümde öğretim elemanlarının, Edmodo uygulamasını kullanarak yaptıkları uygulama etkinliklerine ve bunların öğrencilere sağladığı yararlar hakkındaki gözlemlerine yer verilmiştir. Bu gözlemler sırasıyla Edmodo'nun Türkçe öğretimine katkısına, eğitsel süreçlere katkısına ve kullanışlılığına yöneliktir. 
Tablo 7. Edmodo'nun Türkçe öğretimine katkılarına yönelik öğretici gözlemleri

\begin{tabular}{|c|c|c|}
\hline Tema & $\begin{array}{c}\text { Alt } \\
\text { tema }\end{array}$ & Öğretim Uygulamaları ve Öğretici Gözlemleri \\
\hline \multirow[t]{3}{*}{ 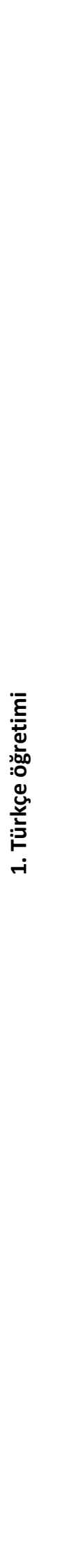 } & 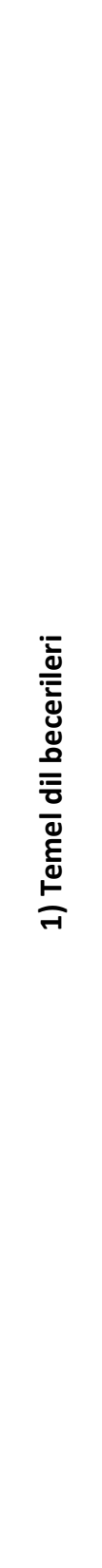 & 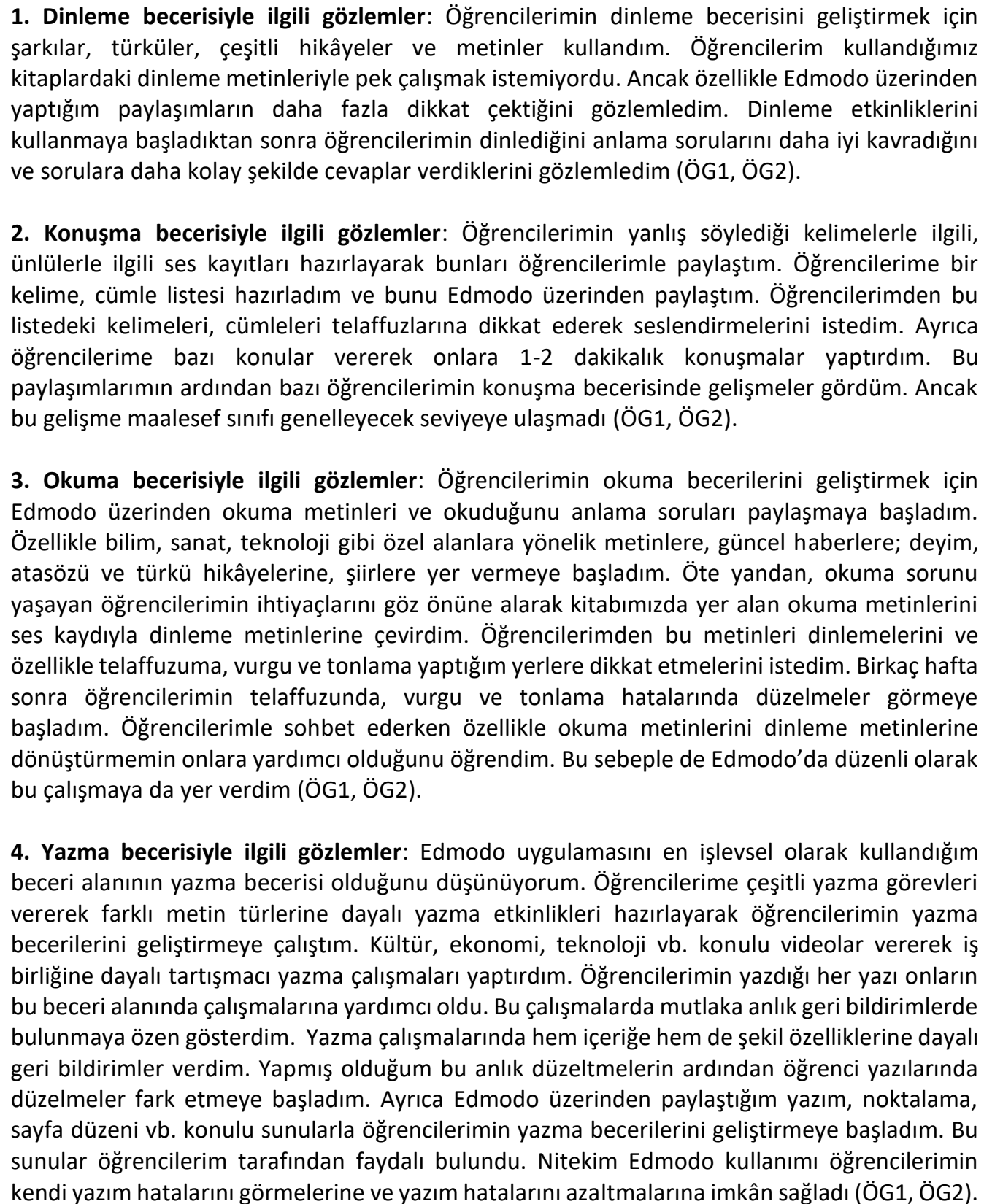 \\
\hline & 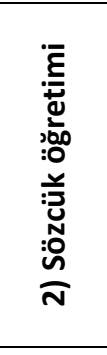 & $\begin{array}{l}\text { - Edmodo üzerinden deyim ve atasözleri hikâyelerini, sözcük oyunlarını ve bazı ders notlarımı } \\
\text { paylaşmaya başladım. Deyim ve atasözü hikâyeleri öğrencilerimin dikkatini çekti ve onları } \\
\text { deyim, atasözü kullanmaya teşvik etti. Öğrencilerim Youtube'de buldukları videoları } \\
\text { paylaşmaya başladılar. Derste merak ettikleri deyimlerin, atasözlerinin anlamlarını sormaya } \\
\text { başladılar. Öte yandan, Edmodo üzerinden yaptığım güncel konulu paylaşımlar da } \\
\text { öğrencilerimin söz varlığını geliştirmeme yardımcı oldu. Öğrencilerim Edmodo üzerinden } \\
\text { öğrendikleri sözcükleri ve söz öbeklerini derslerde kullanmaya başlayınca bu çalışmamın işe } \\
\text { yaradığını görmüş oldum (ÖG1, ÖG2). }\end{array}$ \\
\hline & 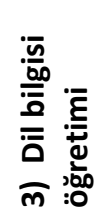 & $\begin{array}{l}\text {-Derslerden önce dil bilgisi konularıyla ilgili sunuları Edmodo üzerinden paylaştım. Derslerde } \\
\text { konuyu anlatırken örneklere dayalı bir sistem kullandım ve bu süreçte sınıftaki çalışmaların } \\
\text { fotoğraflarını çektim. Bunları da Edmodo üzerinden paylaştım. Bu paylaşımlar işimi oldukça } \\
\text { kolaylaştırdı. Paylaştığım ders videoları ve örneklerle dil bilgisi konularını pekiştirdim. } \\
\text { Öğrencilerim bu paylaşımların öğretici ve faydalı olduklarını iletti (ÖG1, ÖG2). }\end{array}$ \\
\hline
\end{tabular}




\begin{tabular}{|c|c|}
\hline 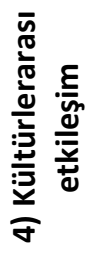 & $\begin{array}{l}\text {-Edmodo'yu kültür aktarımı için de kullandım. Özellikle türkülere, şarkılara; masallara, } \\
\text { efsanelere, hikâyelere yer vererek ve Türk kültürünü aktaran videolar paylaşarak öğrencilerime } \\
\text { Türk kültürünü tanıtmaya çalıştım. Türk kültürüyle ilgili videolar öğrencilerimin dikkatini } \\
\text { çektikten sonra öğrencilerim Türk kültürüyle ilgili sorular da sormaya başladı. Ayrıca bu } \\
\text { paylaşımların ardından kültürler arasındaki benzerlikler ve farklılıklar hakkında daha fazla } \\
\text { konuşmaya başladık (ÖG1, ÖG2). }\end{array}$ \\
\hline 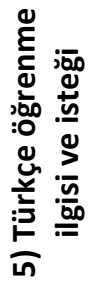 & $\begin{array}{l}\text { - Edmodo'yu kullanmaya başladıktan 2-3 hafta sonra öğrencilerin Edmodo'yu kullanmayı } \\
\text { benimsediklerini ve sevdiklerini gördüm. Özellikle Edmodo'yu sıkça kullanan öğrencilerim kendi } \\
\text { yaptıkları paylaşımlardan mutluluk duyduklarını belirtmeye başladılar. Ayrıca öğrencilerime } \\
\text { kendi kültürlerini tanıtma fırsatı verdiğimde Edmodo'yu daha istekli şekilde kullanmaya ve } \\
\text { düşüncelerini paylaşmaktan mutluluk duymaya başladılar. Açıkçası Edmodo'daki paylaşımlarla } \\
\text { Türkçe öğretmeyi daha eğlenceli hâle getirdiğimi gözlemledim (ÖG1, ÖG2). }\end{array}$ \\
\hline
\end{tabular}

Tablo 8. Edmodo'nun eğitsel süreçlere katkılarına yönelik öğretici gözlemleri

\begin{tabular}{|c|c|c|}
\hline Tema & $\begin{array}{c}\text { Alt } \\
\text { tema }\end{array}$ & Öğretim Uygulamaları ve Öğretici Gözlemleri \\
\hline \multirow{3}{*}{ 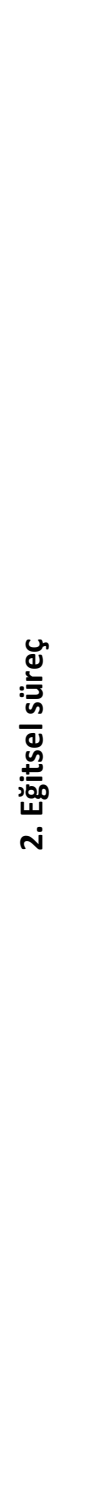 } & 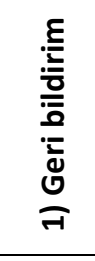 & $\begin{array}{l}\text { - Edmodo uygulamasını kullanırken öğrencilerin tüm paylaşımlarını ve yorumlarını kontrol } \\
\text { ederek onlara geri bildirimler verdim. Bu geri bildirimlere dikkat eden öğrencilerimin kendi } \\
\text { hatalarını daha çabuk görebildiklerini ve bunları telafi edebildiklerini gözlemledim. Ayrıca } \\
\text { öğretim görevlilerinin düzenli olarak paylaşım yapması ve bu paylaşımlara verilen tepkileri } \\
\text { düzenli olarak kontrol edip geri bildirimlerde bulunması Edmodo kullanımı adına çok önem } \\
\text { taşımaktadır (ÖG1, ÖG2). }\end{array}$ \\
\hline & 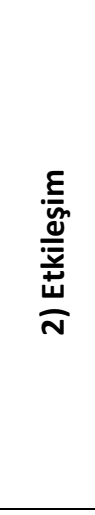 & $\begin{array}{l}\text { - Edmodo'yu kullanmaya başlamadan önce bazı kuralları öğrencilerimle belirledim. Örneğin } \\
\text { kendimizi geliştirebilmek için Edmodo'da sadece Türkçe kullanmaya karar verdik. Herkesin } \\
\text { birbirine saygılı davranması gerektiğine ve sorulan her soruya saygılı şekilde cevap vermemiz } \\
\text { gerektiğine karar verdik. Birlikte karar almamızı Edmodo kullanımımızı etkilediğini } \\
\text { düşünüyorum. Ders içerisinde soru sormaya çekinen birkaç öğrencim Edmodo üzerinden soru } \\
\text { sormaya başladı. Ardından aynı öğrencilerim sınıfta da rahatça soru sormaya başladılar. } \\
\text { Edmodo'daki iletişimin sınıfa da yansıdığını görmüş oldum (ÖG1, ÖG2). } \\
\text {-Nitekim bire bir ilgilenmek için zaman bulamadığım öğrencilerimle Edmodo üzerinden bire bir } \\
\text { ilgilenme fırsatı yakaladım. Bu şekilde de bireysel hataları tespit etmem ve öğrencilerime } \\
\text { bireysel anlamda yardımcı olmam kolaylaştı. Öğrencilerimin kendi hatalarını fark etmeye } \\
\text { başlamaları da gelişimleri adına önemli bir adım oldu (ÖG1, ÖG2). }\end{array}$ \\
\hline & 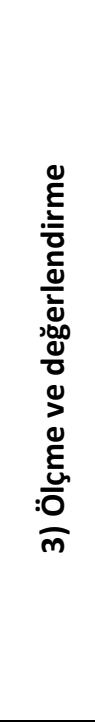 & $\begin{array}{l}\text { - Bugün Edmodo'nun sevdiğim özelliklerinden birisini sınıfta kullandım. Sınıfta Edmodo } \\
\text { üzerinden birkaç sınav paylaştım. Öğrencilerime birbirleriyle yardımlaşabileceklerini de } \\
\text { söyledim. Öğrencilerim sınavları yapıp kendi sonuçlarıyla karşılaştıktan sonra birkaç soruyu } \\
\text { tartışmak istediler. Soruların cevaplarını ben açıklamadım. Gönüllü olan öğrencilerime bu } \\
\text { soruları açıklayabileceklerini söyledim. Öğrenciler hep birlikte soruları çözdüler. Bu şekilde } \\
\text { öğrenciler birbirlerinden bir şeyler öğrendiler. Şunu gördüm ki bu etkinliği daha sık yapmalıyım } \\
\text { çünkü öğrencilerim cevapların açıklamalarını yaparken kendi anlayabilecekleri örneklerden ve } \\
\text { basit ifadelerden yararlandılar. Hem ben bir şey öğrenmiş oldum hem de onlar (ÖG1, ÖG2). } \\
\text { - Edmodo'nun sevdiğim bir diğer özelliği de dijital bir portfolyo özelliğine sahip olması. Dört } \\
\text { haftanın sonunda öğrencilerime şunu sordum: “Edmodo'daki paylaşımlara bakınca kendinizi } \\
\text { geliştirdiğinizi düşünüyor musunuz?” Önce öğrencilerim biraz çekimser kaldılar ancak sınıfın } \\
\text { yarıdan fazlası, Edmodo'daki paylaşımlara, yazdıkları yorumlara, cevapladıkları sorulara ve } \\
\text { kendi yaptıkları paylaşımlara baktıktan sonra Türkçeyi daha iyi bildikleri, kendilerini } \\
\text { geliştirdikleri sonucuna vardılar. Öğrencilerime kendi gelişimlerini görebilecekleri iki-üç örnek } \\
\text { gösterdikten sonra onların da gayet mutlu olduğunu ve Edmodo kullanmaya daha istekli } \\
\text { olduklarını gözlemledim (ÖG1, ÖG2). }\end{array}$ \\
\hline
\end{tabular}




\begin{tabular}{|c|c|}
\hline 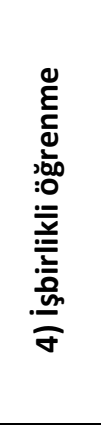 & $\begin{array}{l}\text { - Edmodo'yu kullanma sebeplerimden bir diğeri de işbirlikli çalışmalar yapmak istememdi. } \\
\text { Edmodo'da öğrencilerimin iş birliği içerisinde bir şeyler üretebildikleri etkinlikler hazırladım. } \\
\text { Ayrıca Edmodo dışında da çeşitli işbirlikli etkinlikler hazırladım. Bu etkinlikler sonucunda ortaya } \\
\text { çıkan ürünleri de Edmodo üzerinden paylaştım. Ortaya çıkan ürünlere sınıfça göz atmak ve } \\
\text { bunlarla ilgili olarak geri bildirimler vermek öğrencilerin hoşuna gitti. Gözlemlediğim kadarıyla } \\
\text { işbirlikli etkinliklerle öğrencilerin birbirleriyle olan iletiş̧̧lerini arttırmalarını ve birlikte de } \\
\text { öğrenebileceklerini kavramalarını sağladım. İş birlikli çalışmalarda öğrencilerin daha rahat ve } \\
\text { istekli olduklarını ve birbirlerinden daha fazla istifade ettiklerini gözlemledim. Bu çalışmalar sınıf } \\
\text { iklimini de olumlu şekilde etkiledi. Bu çalışmalardan sonra öğrencilerin birbirlerine daha fazla } \\
\text { soru sormaya başladıklarını gördüm (ÖG1, ÖG2). }\end{array}$ \\
\hline 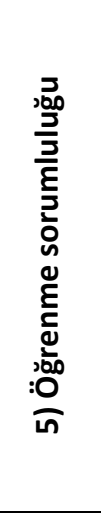 & $\begin{array}{l}\text {-Edmodo'yu kullanmaya başlarken öğrencilerime öğrenme sorumluluğu kazandırmayı da } \\
\text { amaçladım. Bu sebeple de bazı derslerden önce o derste anlatacağım konulara uygun ders } \\
\text { videolarını öğrencilerimle paylaştım. Derslerden sonra da konuları pekiştirmek adına bazı örnek } \\
\text { soruları ve konu anlatım videolarını öğrencilerimle paylaştım. Bu çalışmalarımın öğrencilerin } \\
\text { Türkçe öğrenimine katkı sağladığını görüyorum. Birçok öğrenci ders konularına önceden } \\
\text { hazırlanabildiği için nereyi kavrayamadığını görüp bu bölümlerle ilgili sorular sormaya başladı. } \\
\text { Bazı öğrenciler de Edmodo paylaşımlarıyla konuları pekiştirebildiklerini dile getirdiler. Ayrıca } \\
\text { Türkçe öğrenme ilgisine ve isteğine sahip öğrenciler bu çalışmalarla akranlarına göre daha hızlı } \\
\text { şekilde Türkçeyi öğrenebildiler. Diğer yandan, ileri yaşlardaki öğrencilerim sık sık tekrar yapma } \\
\text { ihtiyacı duydukları için Edmodo paylaşımlarının kendileri için çok faydalı olduğunu ifade ettiler. } \\
\text { Edmodo'daki çalışmalarla öğrencilerimin öz denetim ve öz düzenleme becerilerini geliştirdiğimi } \\
\text { gözlemledim. Çünkü öğrencilerim kendi hatalarından dersler çıkarmaya başladılar (ÖG1, ÖG2). }\end{array}$ \\
\hline 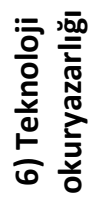 & $\begin{array}{l}\text { - Dikkat çekici hususlardan birisi de teknoloji okuryazarlığı zayıf olan öğrencilerin zamanla daha } \\
\text { iyi birer teknoloji okuryazarı olmalarıydı. Illk başlarda Edmodo'yu ve ona bağlı ikincil } \\
\text { uygulamaları nasıl kullanacağını bilmeyen öğrenciler zamanla farklı uygulamaları çok kısa } \\
\text { sürede kullanmaya başladılar (ÖG1, ÖG2). }\end{array}$ \\
\hline
\end{tabular}

Tablo 9. Edmodo'nun kullanışııı̆̆ına yönelik öğretici gözlemleri

\begin{tabular}{|c|c|c|}
\hline Tema & $\begin{array}{c}\text { Alt } \\
\text { tema }\end{array}$ & Öğretim Uygulamaları ve Öğretici Gözlemleri \\
\hline \multirow{3}{*}{ 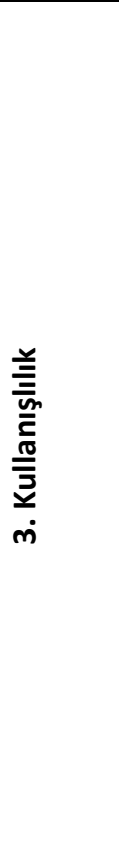 } & 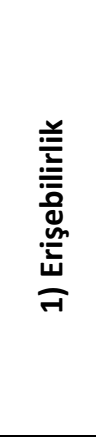 & $\begin{array}{l}\text { - En başından beri Edmodo'yu kullanma sebeplerimden birisi de öğrencilerime istediğim } \\
\text { yerden istediğim zaman ulaşabilmekti. Özellikle Arap kökenli öğrencilerimin kendi dillerini } \\
\text { ve kültürlerini koruma çabasıyla ders dışında Türkçe kullanmadıklarını düşünmeye } \\
\text { başladım. Bazı öğrencilerimle yaptığımız sohbetlerde öğrencilerimin kendi kültürlerini } \\
\text { koruyamama endişesi içinde olduklarını öğrendim. Bu sebeple de onlara hem bazı } \\
\text { açıklamalar yapma ihtiyacı hissettim hem de onlara ders dışında da ulaşmam gerektiğini } \\
\text { anladım. Iş̧te bu temel düşüncem aslında Edmodo'yu kullanma sebebim oldu (ÖG1, ÖG2). } \\
\text {-Edmodo'nun farklı cihazlarda kullanılabilmesi ve internet olan her yerden ona } \\
\text { ulaşılabilmesi öğrencilerin beğenisi kazandı (ÖG1, ÖG2). }\end{array}$ \\
\hline & 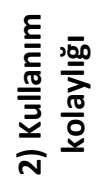 & - Öğrencilerin genel anlamda Edmodo’yu kolaylıkla kullandıklarını gördüm (ÖG1, ÖG2). \\
\hline & 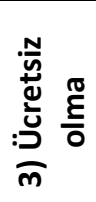 & $\begin{array}{l}\text { - Edmodo'nun ücretsiz olması öğrencilerim tarafından oldukça beğenildi. İlk başlarda } \\
\text { uygulamanın paralı olacağını düşünen öğrencilerim biraz tepki gösterdi. Ancak } \\
\text { uygulamanın ücretsiz olduğunu öğrenen öğrencilerim hızlıca uygulamaya kayıt oldular } \\
\text { (ÖG1, ÖG2). }\end{array}$ \\
\hline
\end{tabular}




\begin{tabular}{|c|c|}
\hline 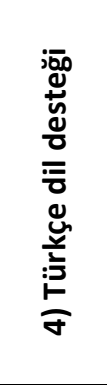 & $\begin{array}{l}\text {-Bugün ilk defa Edmodo'yu kullanmaya başladık. Öğrencilerime adım adım Edmodo'yu } \\
\text { anlattım. Birlikte Edmodo'ya kayıt olduk ve Edmodo menülerini tanıdık. Bazı öğrencilerimin } \\
\text { Türkçe ara yüze sahip programa üye olmakta, programı kullanmakta zorlandıklarını gördüm. } \\
\text { Açıkçası bu beni biraz şaşırttı. Aslında Edmodo, Facebook'a çok benziyor ve öğrencilerimin } \\
\text { hepsi de Facebook'u kullanıyor. Öğrencilerime neden bu programı kullanmakta } \\
\text { zorlandıklarını sorduğumda birçoğu telefonlarındaki uygulamaları Arapça kullandıkları için } \\
\text { Türkçe olan bu programda zorlandıklarını ifade ettiler. Şuna karar verdim: Edmodo ile } \\
\text { uyumlu çalışan Edpuzzle, Blendspace (Tes) vb. araçları da öğrencilerime kullandırtmaya } \\
\text { başlayacağım (ÖG1, ÖG2). }\end{array}$ \\
\hline 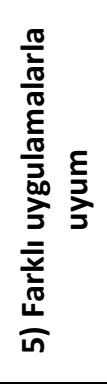 & $\begin{array}{l}\text { - Edmodo kullanmaya başlayalı altı hafta oldu. Edmodo ile birlikte Edpuzzle, Blendspace } \\
\text { (Tes), Kahoot vb. araçları da kullandık. İlk başlarda öğrencilerim programları kullanmakta } \\
\text { zorlandılar. Ancak içlerinden iki-üç kişi kolayca programları kullanmaya başladı. Bunun } \\
\text { üzerine onları "teknoloji liderleri" olarak seçtim ve onlardan arkadaşlarına yardımcı } \\
\text { olmalarını istedim. Teknoloji liderlerinin yardımlarıyla kısa sürede farklı araçları ve elbette } \\
\text { ki Edmodo'yu daha etkin şekilde kullanmaya başladık. Bu süreçte öğrencilerimin teknoloji } \\
\text { okuryazarlığının ve görsel okuryazarlığının geliştiğine şahit oldum. Başlangıçta Edmodo’ya } \\
\text { kayıt olmakta ve Edmodo'yu kullanmakta zorlanan öğrencilerim yeni uygulamalara kolayca } \\
\text { uyum sağladılar (ÖG1, ÖG2). }\end{array}$ \\
\hline 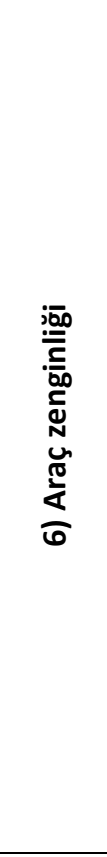 & $\begin{array}{l}\text { - Bugün Edmodo kullanmaya başlayalı neredeyse bir hafta oluyor. Edmodo üzerinden anket } \\
\text { oluşturup öğrencilerin ihtiyaçlarını ve isteklerini belirlemeye çalıştım. Açıkçası anketler } \\
\text { oldukça kullanışı araçlar. Ayrıca duyuru servisi aracılığıyla yaklaşan etkinlikleri, ödevleri, } \\
\text { sınavları hatırlatabilmek; sınavlardan önce ödevler, etkinlikler ve farklı soru çeşitlerine sahip } \\
\text { sınavlar ile öğrencilerin durumlarını tespit edebilmek; gerekli ders dokümanlarını kolayca } \\
\text { öğrencilerle paylaşabilmek ve öğrencilerin istedikleri yerden ulaşarak bana ve arkadaşlarına } \\
\text { soru sorabilmeleri bu uygulamanın diğer olumlu yönlerinden birkaçıdır (ÖG1, ÖG2). } \\
\text { - Bir aylık bir sürecin sonunda öğrencilerime “Ayın Öğrencisi”, "Yorum Canavarı”, "Soru } \\
\text { Kralı”, "Üretken Beyin”, "Paylaşım Ustası" gibi rozetler verdim. Bu rozetler öğrencilerimin } \\
\text { hesaplarında görülebiliyor. Açıçası, bu rozetlerin işe yaramadığını düşünüyordum ancak bu } \\
\text { rozetleri verdikten bir gün sonra sınıfta konuşulan konunun bu olduğunu gördüm. Rozet } \\
\text { alanlar o gün derste daha mutlu ve istekliydi. Diğer öğrencilerim ise kendilerine neden bu } \\
\text { rozetlerden vermediğimi sordular. Ben de bu rozetlerin anlamlarını ve hangi görevleri } \\
\text { yerine getirdikleri için öğrencilerime bu rozetleri verdiğimi detaylıca açıkladım. Dersten } \\
\text { sonraki akşam gördüm ki daha önce Edmodo kullanmayı önemsemeyen ya da istemeyen } \\
\text { kişiler daha fazla Edmodo'da katılım göstermeye başladılar. Ben de rozetleri haftalık } \\
\text { vermeye karar verdim ve katılımcı öğrencilerime “Haftanın Yıldızı", "Yükselen Değer" gibi } \\
\text { rozetler verdim. Bu rozetlerin her yaştan öğrenciler için etkili bir araç olabileceğini öğrendim } \\
\text { (ÖG1, ÖG2). }\end{array}$ \\
\hline
\end{tabular}

Tablo 10. Edmodo'nun eksikliklerine yönelik öğretici gözlemleri

\begin{tabular}{|c|c|c|}
\hline Tema & $\begin{array}{c}\text { Alt } \\
\text { tema }\end{array}$ & Öğretim Uygulamaları ve Öğretici Gözlemleri \\
\hline 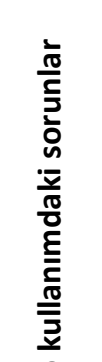 & 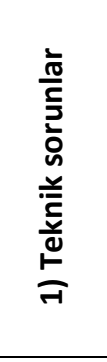 & $\begin{array}{l}\text { - Edmodo'nun gördüğüm en ciddi sorunu özellikle android tabanlı cihazlarda hata veriyor } \\
\text { olmasıydı. Açıkçası iOS tabanlı cihazlarda uygulamanın çok daha düzgün çalıştığını } \\
\text { gözlemledim (ÖG1, ÖG2). } \\
\text { - Edmodo'nun beğenmediğim bir diğer özelliği de öğrencilerime rozetleri bilgisayar } \\
\text { üzerinden vermem ve bu rozetleri mutlaka bilgisayar üzerinden düzenlemem } \\
\text { gerekmesiydi. Buradaki işlemleri de telefonum üzerinden yapabilmek daha kolay olacaktı } \\
\text { (ÖG1, ÖG2). }\end{array}$ \\
\hline 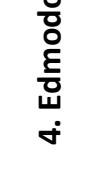 & 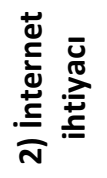 & $\begin{array}{l}\text { - Edmodo'nun beğenmediğim bir diğer yönü de internet bağlantısına sürekli ihtiyaç } \\
\text { duyulmasıdır. Bazı öğrencilerimin kişisel cihazlarında internet olmadığı için sınıf } \\
\text { çalışmalarına katılamama durumları oldu. Edmodo'ya çevrimdışı ulaşamamak } \\
\text { öğrencilerimin tepkisini çekti (ÖG1, ÖG2). }\end{array}$ \\
\hline
\end{tabular}




\begin{tabular}{|c|c|}
\hline 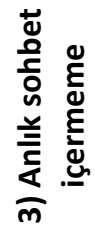 & $\begin{array}{l}\text { - Öğrencilerimle sohbet ettiğimde Edmodo'nun anlık iletişime imkân sunacak çevrim içi } \\
\text { bir sohbet odasına sahip olmamasının onlar için bir sorun olduğunu anladım (ÖG1, ÖG2). }\end{array}$ \\
\hline 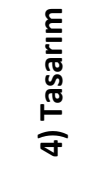 & $\begin{array}{l}\text { - Özellikle başlangıçta Edmodo'nun ara yüzü çok soğuk ve eğlencesiz gözüküyor. Bu } \\
\text { sebeple ilk günlerde öğrencilerin Edmodo kullanmaya pek de sıcak bakmadıklarını } \\
\text { gözlemledim (ÖG1, ÖG2). }\end{array}$ \\
\hline 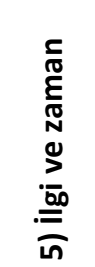 & $\begin{array}{l}\text { - Açıkçası Edmodo öğretim görevlilerinin öğrencilerine ders dışında, farklı bir alanda da } \\
\text { ulaşmasını sağlasa da öğretmenlerin özel ilgisini, çabasını ve zamanını istemektedir. } \\
\text { Öğretmenlerin düzenli olarak paylaşım yapması ve bu paylaşımlara verilen tepkileri } \\
\text { düzenli olarak kontrol edip geri bildirimlerde bulunması Edmodo kullanımı adına çok } \\
\text { önem taşımaktadır. Öğrencilerine sınıf dışında da bir şeyler öğretmek isteyen öğretmenler } \\
\text { için bu uygulama gerçekten çok yardımcıdır (ÖG1, ÖG2). }\end{array}$ \\
\hline
\end{tabular}

\section{Sonuç ve Tartışma}

Bu araştırmada, Türkçenin yabancı dil olarak öğretiminde Edmodo kullanımı, öğrenci görüşleri ve öğretim elemanları gözlemlerine dayalı olarak değerlendirilmiştir. Bu doğrultuda elde edilen veriler çözümlenerek Edmodo uygulamasının "Türkçe öğrenmeye katkısı, eğitsel yararları ve kullanışlılı̆ı" temalarına ulaşıımıştır.

Araştırmanın bulgularına göre Edmodo'nun dil öğreniminde temel dil becerilerinin geliştirilmesine, yeni sözcük ve söz öbeklerinin öğrenilmesine, dil bilgisi kurallarının öğrenilmesine, hedef kültürün ve farklı kültürlerin aktarımına, Türkçe öğrenme ilgisine ve isteğine katkı sağladığı tespit edilmiştir.

Araştırmanın bulgularına göre öğrenciler, Edmodo uygulamasının sırasıyla yazma, dinleme, okuma ve konuşma becerilerinin gelişimine katkı sağladığını belirtmişlerdir. Uygulama sürecini yürüten öğretici gözlemleri de öğrencilerin bu görüşleriyle tutarlıdır. Nitekim Yaman (2014), İngilizce öğrencileri ile yaptığı araştırmasında, Edmodo üzerinden yapılan çevrimiçi okuma çalışmalarının öğrenciler tarafından daha hızlı ve eğlenceli, öğrenme ilgisini ve isteğini artırıcı bulunduğunu ortaya koymuştur. Aynı şekilde Al-Kathiri (2015) de İngilizcenin yabancı dil olarak öğretiminde Edmodo kullanımının öğrenme ve öğretme süreçlerini kolaylaştırıcı özelliklere sahip olduğunu tespit etmiştir. Öte yandan Dere, Yücel ve Yalçınalp (2016), ilköğretim öğrencileri üzerine yaptıkları araştırmada, öğrencilerin yarısının (\%50) Edmodo'nun öğrenmelerini olumlu etkilediği konusunda hem fikir olduklarını belirtmiştir. Ayrıca Dere ve diğ. (2016), öğrencilerin yarısından az $(\% 46,1)$ bir kısmının Edmodo'nun yazma becerilerini geliştirdiği düşüncesini savunduklarını tespit etmiştir. Dere, Yücel ve Yalçınalp (2016) bu durumu Edmodo'nun doğrudan yazma becerilerini geliştirmek için oluşturulmuş bir platform olmamasına bağlamıştır. Ancak burada gözden kaçırılmaması gereken husus, Edmodo'nun sahip 
olduğu araçlarla çok farklı beceri alanları için de kullanılabilir olmasıdır. Edmodo, sahip olduğu birçok araçla etkinliklerin öğrenci ihtiyaçlarına ve öğretim kazanımlarına uygun olacak şekilde yapılandırımasına imkân tanımıştır. Burada, Edmodo'yu öğretim aracı olarak kullanan eğitimcilere ciddi sorumluluklar düşmektedir. Araştırmanın bulgularına göre Türkçeyi yabancı dil olarak öğrenen öğrenciler, Edmodo uygulamasının en fazla yazma becerilerinin $(\% 36,8)$ gelişimine katkı sağladığını düşünmektedir. Oysa yapılan bu araştırmada elde edilen veriler, Dere, Yücel ve Yalçınalp (2016)'ın araştırma bulguları ile örtüşsmemektedir. Bunun sebebi ise araştırmacıların yazma becerisine yönelik özel etkinlikler geliştirip uygulamamaları olabilir. Bununla birlikte Edmodo'nun dil öğrenim ilgisine ve isteğine katkı sağladığı bulgusu alanyazındaki bulgularla (Al-Kathiri, 2015; Aytan ve Başal, 2015; Özkan, 2017; Türkmen, 2012; Yaman, 2014) örtüşmektedir.

İkinci olarak Edmodo'nun geri bildirim verme, etkileşim kurma, ölçme ve değerlendirme, işbirlikli öğrenme, öğrenme sorumluluğu kazandırma ve teknoloji okuryazarlığı gibi eğitsel süreçlere katkı sağladığı öğrencilerce ifade edilmiştir. Araştırmacıların gözlemleri de bu düşünceleri destekler niteliktedir. Aynı zamanda bu araştırmada elde edilen bulgular, konuyla ilgili daha önce yapılan benzer araştırmaların; öğrenci görüşlerine ve öğretmen gözlemlerine dayalı çalışmaların geri bildirim verme ve etkileşim kurma (Aytan ve Başal, 2015; Dewi, 2014; Polat, 2016; Torun ve Dargut, 2015), ölçme ve değerlendirme (Ekmekçi, 2016), işbirlikli öğrenme (McClain, Brown ve Price,2015; Sırakaya, 2014), öğrenme sorumluluğu kazandırma (Balasubramanian, Jaykumar ve Fukeyb, 2014; Holland ve Muilenburg, 2011; Sanders, 2012) ve teknoloji okuryazarlığını geliştirme (Aytan ve Başal, 2015) üzerine tespit edilen bulguları ile benzerlikler göstermektedir.

Üçüncü olarak da öğrenci görüşleri ve araştırmacıların gözlemleri doğrultusunda Edmodo'nun erişilebilirlik, kullanım kolaylığı, ücretsiz olma, Türkçe dil desteği, farklı uygulamalarla uyum ve araç zenginliği gibi "kullanışlılık" özelliklerine sahip olduğu belirlenmiştir. Araştırmacıların gözlemleri de öğrencilerin bu düşünceleri ile benzerdir. Bu veriler, Edmodo üzerine yapılan daha önceki araştırmaların bulguladığı; Edmodo'nun kolay erişilebilir olması (Özkan, 2017; Torun ve Dargut, 2015); ücretsiz ve kullanım kolaylığına sahip olması (Alemdağ, 2013; Balasubramanian, Jaykumar ve Fukeyb, 2014; Durak, Çankaya ve Yünkül 2015; Holland ve Muilenburg, 2011; Sırakaya, 2014; Türkmen, 2012); araç zenginliğine sahip olması (Dere, Yücel ve Yalçınalp, 2016; Kazez ve Bahçeci, 2016; Özkan, 2017; Polat, 2016) verileriyle örtüşmektedir.

Son olarak Edmodo'nun bazı teknik sorunlar içermesi, internet bağlantısı olmadan çalışmaması, anlık sohbet özelliğine sahip olmaması, tasarım özellikleri bakımından beklentilere cevap verememesi gibi olumsuz özelliklere sahip olduğu tespit edilmiştir. Edmodo'nun tespit edilen olumsuz taraflarına araştırma içerisinde "Edmodo'daki sorunlar" teması altında yer verilmiştir. Araştırma sürecinde tespit edilen bu sorunlar ve eksiklikler Edmodo'yla ilgili olarak alanyazında yapılan 
eleştirilerle (Sırakaya, 2014) örtüşmektedir. Diğer yandan öğretim elemanları, Edmodo'yu bazı menülerinin tamamen Türkçe olmaması nedeniyle de eleştirmiştir. Ancak bu durumla ilgili olarak çalışmada herhangi bir öğrenci görüşüne rastlanmamıştır. Çalışma grubundaki öğrencilerin bu eksikliği fark etmemelerinin nedeni, yabancı dil bilmeleriyle açıklanabilir. Bu bulgu, Sırakaya (2014)'nın öğretmen adaylarından elde ettiği bulgu ile ters düşmektedir. Bu durumun sebebi Sırakaya (2014)'nın çalışmasını öğretmen adaylarıyla yapmasına bağlanabilir. Tüm bu bulgular ışığında Edmodo'nun Türkçenin yabancı dil olarak öğretiminde bir öğrenme-öğretme aracı olarak kullanılabileceği söylenebilir.

\section{Kaynaklar}

Ajjan, H., \& Hartshorne, R. (2008). Investigating faculty decisions to adopt WEB 2.0 technologies: theory \& empirical tests. The Internet \& Higher Education 11(2), 71-80.

Alemdağ, E. (2013). Edmodo: Eğitsel bir çevrimiçi sosyal öğrenme ortamı. In İnetTr'13, XVIII. Türkiye'de İnternet Konferansı 18. cilt (pp. 71-77). İstanbul Üniversitesi, 9-11 Aralık 2013.

Al-Kathiri, F. (2015). Beyond the classroom walls: edmodo in saudi secondary school efl instruction, attitudes and challenges. English Language Teaching, 8(1), 189-204.

Aydın, B., \& Demirer, V. (2016). Flipping the drawbacks of flipped classroom: effective tools and reccomendations. Journal of Educational and Instructional Studies In The World, 6(1), 33-40.

Aytan, T., \& Başal, A. (2015). Türkçe öğretmen adaylarının web 2. 0 araçlarına yönelik algılarının incelenmesi. International Periodical For The Languages, Literature and History of Turkish or Turkic, 10(7), 149-166.

Balasubramanian, K., Jaykumar, V., \& Fukeyb, L. N. (2014). A study on "student preference towards the use of edmodo as a learning platform to create responsible learning environment. Procedia - Social and Behavioral Sciences, 144, 416-422.

Baştuğ, İ., Solmaz, İ., Kaledibi, F. ve İşbulan, O. (2016). 5. ve 6. sınıf öğrencilerinin programlama eğitiminde edmodo kullanımına dair yönelik görüşlerinin belirlenmesi. 4. International Instructional Technologies and Teacher Education Symposium. (pp.76-83). Fırat Üniversitesi, 6-8 Ekim 2016.

Büyüköztürk, Ş., Çakmak, E. K., Akgün, Ö. E., Karadeniz, Ş., \& Demirel, F. (2014). Bilimsel araştırma yöntemleri. Ankara: Pegem Akademi Yayıncılık.

Creswell, J. W. (2016). Araştırma deseni nitel, nicel ve karma yöntem yaklaşımları. Demir, S. B. (çev. ed.) (2. baskı). Ankara: Eğiten Kitap.

Çepni, S. (2014). Araştırma ve proje çalışmalarına giriş. Trabzon: Celepler Matbaacılık.

Dere, E., Yücel, Ü. A. ve Yalçınalp, S. (2016). İlköğretim öğrencilerinin eğitsel bir çevrimiçi sosyal öğrenme ortamı olan Edmodo'ya ilişkin görüşleri. Elementary Education Online, 15, 3, 804-819.

Dewi, F. (2014). EDMODO: A social learning platform for blended learning class in higher education . Research in Education Technology: Pedagogy and Technology Journal, 1-11.

Dogoriti, E., \& Pange, J. (2014). Instructional design for a "social" classroom: Edmodo and Twitter in the foreign language classroom. ICICTE 2014 Proceedings, 154-165.

Durak, G., Çankaya, S. \& Yünkül, E. (2014). Eğitimde eğitsel sosyal ağ sitelerinin kullanımı: Edmodo örneği. Dumlupınar Üniversitesi Sosyal Bilimler Dergisi, 41, 309-316.

Durmuş, A. (2015). WEB 2.0 araçları ve eğitsel uygulamalar. (Edt. Buket Akkoyunlu, Aytekin İşman ve Hatice F. Odabaşı). Eğitimde Teknoloji Okumaları içinde s.109-127. Ankara: TOJET.

Edmodo, 2018. https://go.edmodo.com/about/ 30.05.2018 tarihinde erişilmiştir. 
Ekmekçi, E. (2016). Integrating Edmodo into foreign language classes as an assessment tool. participatory educational research (PER). Special Issue 2016-I, pp., 1-11.

Enriquez, M. A. (2014). Students"perceptions on the effectiveness of the use of Edmodo as a supplementary tool for learning . Presented at the DLSU Research Congress 2014. Manila, Philippines: De La Salle University.

Gliner, J. A., Morgan, G.A. ve Leech, N. (2015). Uygulamada araştırma yöntemleri. Ankara: Nobel Yayınevi.

Hamutoğlu, N. B. ve Kıyıcı, M. (2017). Bir eğitsel sosyal ağ olarak Edmodo'nun yükseköğretimde kullanımına yönelik öğrenci görüşlerinin incelenmesi. Trakya Üniversitesi Eğitim Fakültesi Dergisi, 7, 2, 322-343.

Holland, C., \& Muilenburg, L. Y. (2011). Supporting student collaboration: Edmodo in the classroom. In Society for Information Technology \& Teacher Education International Conference, (s. 3232-3236).

Holzweiss, K. (2013). Edmodo: a great tool for school librarians. School Library Monthly, v29 n5 p14-16.

Horzum, M. B. (2010). Öğretmenlerin WEB 2.0 araçlarından haberdarlığı, kullanım sıklıkları ve amaçlarının çeşitli değişkenler açısından incelenmesi. Uluslararası Insan Bilimleri Dergisi, 7, 1, s.603-634.

Kazez, H., ve Bahçeci F. (2016). BÖTE bölümü öğretmen adaylarının Edmodo kullanımına dair görüşlerinin incelenmesi. Eğitim ve Öğretim Araştırmaları Dergisi, 5(1), 9-20.

Kongchan, C. (2008). How a non-digital-native teacher makes use of Edmodo. In 5th Intenational Conference ICT for Language Learning. Florence.

Kurt, A.A. ve Orhan, D. (2015). Okuryazarlıkların yükseköğretime yansımaları. (Edt. Buket Akkoyunlu, Aytekin İşman ve Hatice F. Odabaşı). Eğitimde Teknoloji Okumaları içinde s.65-83. Ankara: TOJET.

Kuzgun, H. ve Özdinç, H. (2017). Eğitsel sosyal ağ ortamı Edmodo'nun kullanılabilirliğinin incelenmesi. $A K U$ Kuramsal Eğitimbilim Dergisi, 10, 2, 274-297.

Merriam, S. B. (2015). Nitel araştırma desen ve uygulama için bir rehber. Ankara: Nobel Yayınevi.

McClain, C., Brown, A., \& Price, G. (2015). Characterization personified: using Edmodo to strengthen student interaction with literature. Meridian, 1-19.

Nee, C. K. (2014). The effect of educational networking on students performance in biology. TCC Worldwide Online Conference, (s. 73-97).

Özkan, A. (2017). Öğretim elemanlarının eğitsel sosyal ağ kullanım deneyimlerinin incelenmesi: Edmodo örneği. (Yayımlanmamış yüksek lisans tezi). Atatürk Üniversitesi Eğitim Bilimleri Enstitüsü: Erzurum.

Paker, T. (2015). Durum çalışması. (edt. Fatma Nevra Seggie ve Yasemin Bayyurt). Nitel araştırma içinde (119135). Ankara: Anı Yayıncılık.

Paliktzoglou, V., \& Suhonen, J. (2014). Microblogging in higher education: the Edmodo case study among computer science learners in Finland. Journal of Cases on Information Technology, 16(2), 39-57.

Partnership For 21st Century Skills, (P21). (2018). Framework for 21st century learning. 30 Mayıs 2018 tarihinde http://www.p21.org/about-us/p21-framework sayfasından erişilmiştir.

Polat, O. (2016). Eğitsel sosyal medya platformları ve Edmodo örnek uygulaması. (Yayımlanmamış yüksek lisans tezi). Necmettin Erbakan Üniversitesi Eğitim Bilimleri Enstitüsü: Konya.

Sanders, K. S. (2012). An examination of the academic networking site Edmodo on student engagement and responsible learning. (Unpublished doctoral dissertation). University of South Carolina College of Education.

Sırakaya, M. (2015).Öğretmen adaylarının Edmodo hakkındaki görüşleri. Teacher candidates' views on Edmodo. 8th International Computer \& Instructional Technologies Symposium, Edirne, Turkey.

Solomon, G. ve Schrum, L. (2007). WEB 2.0 new tools, new schools. Washington: İste. 
Torun, F., \& Dargut, T. (2015). Mobil öğrenme ortamlarında ters yüz sınıf modelinin gerçekleştirilebilirliği üzerine bir öneri. Adnan Menderes Üniversitesi Eğitim Fakültesi Eğitim Bilimleri Dergisi, 6(2), 20-29.

Türkmen, H. G. (2012). Using social networking in EFL classroom in higher education. The 8th international scientific conference e-learning and software for education. pp. 350-354.

Yaman, M. (2014). İngilizceyi yabancı dil olarak öğrenen öğrencilerin çevrimiçi otantik okumalara karşı olan algılarının belirlenmesi. Yayımlanmamış Yüksek Lisans Tezi. Ankara: Orta Doğu Teknik Üniversitesi Sosyal Bilimler Enstitüsü.

Yıldııım, A. \& Şimşek, H. (2013). Sosyal bilimlerde nitel araştırma yöntemleri. Ankara: Seçkin Yayıncılık.

\section{Extended Abstract Introduction}

In recent years, technology has started to be used in teaching Turkish as a foreign language. One of the most frequently used technologies in language teaching environments is the internet-based WEB 2.0 tools. One of the most commonly used WEB 2.0 tools in language teaching is Edmodo. There are many studies on the use of Edmodo application for educational purposes. Those investigations are compilation-style studies that introduce Edmodo and explain how to use it. Apart from these, there are studies from various branches of science, examining the views of the university faculty, school teachers or prospective teachers about Edmodo; there are also studies that study the views of students regarding Edmodo. Those studies focus on Edmodo's usability as a teaching tool and ease of use, its effect on student achievement in different skill areas, its effect on the interest and desire of learning, and its effect on classroom interaction. There are also studies that focus on the role of Edmodo as a social networking tool. However, no research has been conducted on the views of the students and the observations of the instructors regarding the use of Edmodo in teaching Turkish as a foreign language. In this study, student views and instructor observations regarding the use of Edmodo in teaching Turkish as a foreign language were examined.

\section{Method}

In this research which was designed as a case study, firstly, the opinions of the B2 level students on the use of Edmodo in Turkish lessons were examined. In the same way, the observations of the instructors on the application were analyzed. The study group was determined through purposeful sampling. The participants were 20 B2 level students. Two instructors who taught Turkish courses to the students in the same institution and were able to use Edmodo effectively were included in the study. The instructors used Edmodo for practice in their lessons for 8 weeks. Edmodo contributed to the teaching process in two ways:

1. In-class applications: In group work while doing creative writing, Edmodo helped students in terms of spelling, punctuation, grammar, and finding contextually appropriate vocabulary. It was also useful to the instructors in terms of giving feedback, correction, measurement and evaluation.

2. Out-of-class applications: Edmodo contributed to student learning in the areas of improving their pronunciation, reading comprehension and its evaluation, listening comprehension and its evaluation, creative writing, teaching and reinforcing the spelling rules, punctuation, and grammar, choosing contextually appropriate words and phrases. Edmodo also contributed to the teaching of national and religious festivals, clothing, food and beverages, and myths and customs of the Turkish culture.

In order to provide detailed and in-depth data on Edmodo, the "Edmodo Interview Form", consisting of semi-structured, open-ended questions was given to the students at the end of 8 weeksand was answered by the students. The interviews with the students about the implementation were conducted to inform the students about the questions that were unclear or were not answered adequately in writing and to obtain detailed and in-depth data.

For data analysis, content analysis was used. Data analysis revealed three main categories of students' opinions regarding the use of Edmodo in learning Turkish. Students whose opinions were sought were coded as P1, P2 so as not to reveal their identities. Likewise, instructors were coded as II and I1. The data obtained from the the two groups led to the following main and sub-themes:

1. Edmodo's contribution to learning and teaching Turkish

2. Edmodo's contribution to educational processes

3. Edmodo's usefulness 


\section{Result and Discussion}

According to the findings of the research, firstly, it was found that Edmodo contributes to the development of basic language skills in learning languages, learning new words and phrases, learning grammar rules, intra and intercultural communication, and interest and desire of learning Turkish.

Secondly, Edmodo contributes to educational processes such as giving feedback, interaction, measurement and evaluation, cooperative learning, taking responsibility for learning and technological literacy.

Thirdly, it was found that Edmodo has utility features such as accessibility, ease of use, free of charge, Turkish language support, and adaptation to different applications. Instructors' opinions are parallel to these findings.

Finally, it was found that Edmodo has some negative features such as not becoming operational without an internet connection, lacking an instant chat feature, and failing to satisy user expectations in terms of design faults. Those negative aspects are presented under the theme "Problems in Edmodo".

The overall findings show that Edmodo can be used as a learning-teaching tool in the field of teaching Turkish as a foreign language. 